\title{
Symbolic character productions in the mousterian site of La Roche-Cotard in Langeais (Indre-et-Loire, France) and their geological context
}

Les productions à caractère symbolique du site moustérien de La Roche-Cotard à Langeais (Indre-et-Loire, France) dans leur contexte géologique

Jean-Claude Marquet, Michel Lorblanchet, Yves Egels, José EsquerrePourtère and Maria-Sibylla Hesse

OpenEdition

\section{Journals}

\section{Electronic version}

URL: http://journals.openedition.org/paleo/3013

DOI: $10.4000 /$ paleo.3013

ISSN: 2101-0420

Publisher

SAMRA

\section{Printed version}

Date of publication: 28 December 2014

Number of pages: 169-194

ISSN: 1145-3370

\section{Electronic reference}

Jean-Claude Marquet, Michel Lorblanchet, Yves Egels, José Esquerre-Pourtère and Maria-Sibylla Hesse, «Symbolic character productions in the mousterian site of La Roche-Cotard in Langeais (Indreet-Loire, France) and their geological context », PALEO [Online], 25 | 2014, Online since 28 July 2015 connection on 07 July 2020. URL : http://journals.openedition.org/paleo/3013 ; DOI : https://doi.org/ 10.4000/paleo.3013

This text was automatically generated on 7 July 2020.

\section{c)}

PALEO est mis à disposition selon les termes de la licence Creative Commons Attribution - Pas d'Utilisation Commerciale - Pas de Modification 4.0 International. 


\section{Symbolic character productions in the mousterian site of La Roche- Cotard in Langeais (Indre-et-Loire, France) and their geological context}

Les productions à caractère symbolique du site moustérien de La Roche-Cotard à Langeais (Indre-et-Loire, France) dans leur contexte géologique

Jean-Claude Marquet, Michel Lorblanchet, Yves Egels, José EsquerrePourtère and Maria-Sibylla Hesse

Acknowledgements to Philippe Brule and Dimitry Ferey, surveyors for the Cave Union 37, to the reviewers of the Paleo journal for their comments and advice, to J.-J. Macaire and H. Guillemot for their reviewing of the text and to Mr and Mrs. Bernard Menassanch, owners of the cave and Ms. Marcelle Menassanch.

The works on the site are funded by the State (DRAC / SRA Centre), the Regional Council of the Centre (ARCHEA Association) and Cofiroute Company.

La Roche-Cotard (LRC) site is located by the town of Langeais in the Indre-et-Loire region, France. It develops halfway up the slope on the right bank of the Loire valley just upstream of the town and west of Cinq-Mars-la-Pile. It is therefore south-facing; it consists of a cave, a station at the foot of the cliff, a small very low shelter and a caveshelter of small dimensions. It is not impossible that the knowledge we have today is incomplete due to its geological context and the very particular circumstances that led to the discovery. While a Mousterian layer yielded the mask of La Roche-Cotard, an object many experts now consider as a symbolic production of the Neanderthals, and as various recent discoveries are broadening the question of the skills of the predecessor of modern humans in Western Europe, it was appropriate to bring to the attention of the scientific community other productions from this site that will be considered here. 


\section{1 - History of the discovery and research on the site}

2 Until the mid-nineteenth century, and for a number of preceding millennia, the site was completely masked by slope deposits whose geometry can be known thanks to natural profiles visible a few hundred meters downstream and upstream of the site.

In 1846, the construction of the railway line from Tours to Angers required huge amounts of materials that were taken from the foot of the valley slope, nearest to the part to elevate. Thus in the current park of La Roche-Cotard estate (fig. 1), large masses of sediment were removed, undermining the slope and advancing in various proportions toward the edge of the plateau. The entrance to the cave may have been opened but it was not really discovered then or, if it was, no interest was given to it by the workers who loaded the dirt carts.

4 It is possibly because the cave is located within a fenced private estate that the real discovery was delayed. Indeed, François d'Achon, the owner, entered the cave in January 1912 (d'Achon 1913). With his workers, he excavated most of the content in a few weeks and found numerous bones and knapped flints (we will use the term flint for the siliceous material brought onto the site and knapped), especially at the entrance and in the first part of the cave.

5 New research was undertaken in the 1970s, in three campaigns, in 1975, 1976 and 1977. Our aim was twofold: to identify the existence of remains of archaeological layers inside the cave and to carry out a survey pit at the entrance of the cave in search of possible intact occupation levels.

6 The three excavation campaigns yielded extremely interesting results (Marquet, 1979, 1997) (fig. 2), which can be summarized as:

- The discovery of fragments of layers, sometimes quite substantial, intact, in the F. d'Achon cave (LRC I);

- The discovery of an intact Mousterian level in the excavation conducted in front of the entrance of the cave (LRC II); it is the latter that yielded the La Roche-Cotard mask;

- Finally, the discovery, a little further east, of a low shelter (LRC III) filled with sediment (fig. 2).

7 Between 1975 and 1977, little work was carried out inside the cave (LRC I) but we had already examined the walls. The existence of a very thin film of sediment was observed as well as the curious natural "withdrawal" of the wall from its base to a certain height, always constant in all the first half of the cave. Finally, the presence of traces of various kinds on the walls was noted, some of which appeared to have been made by fingers.

From 2008, new research has revealed, further east, a small cave shelter masked by a 10 meter-high impressive succession of strata in LRC IV (Ajas 2011). They mostly helped to resume the study of the walls of the d'Achon cave and to do the tracing of a number of marks, the topic of the present paper. Two series of dating have also been carried out, one by the $14 \mathrm{C}$ method on bones and the other by the OSL (Optically Stimulated Luminescence) method on sandy sediments. 
Figure 1 - La Roche-Cotard in Langeais, Indre-et-Loire. Geographical location.

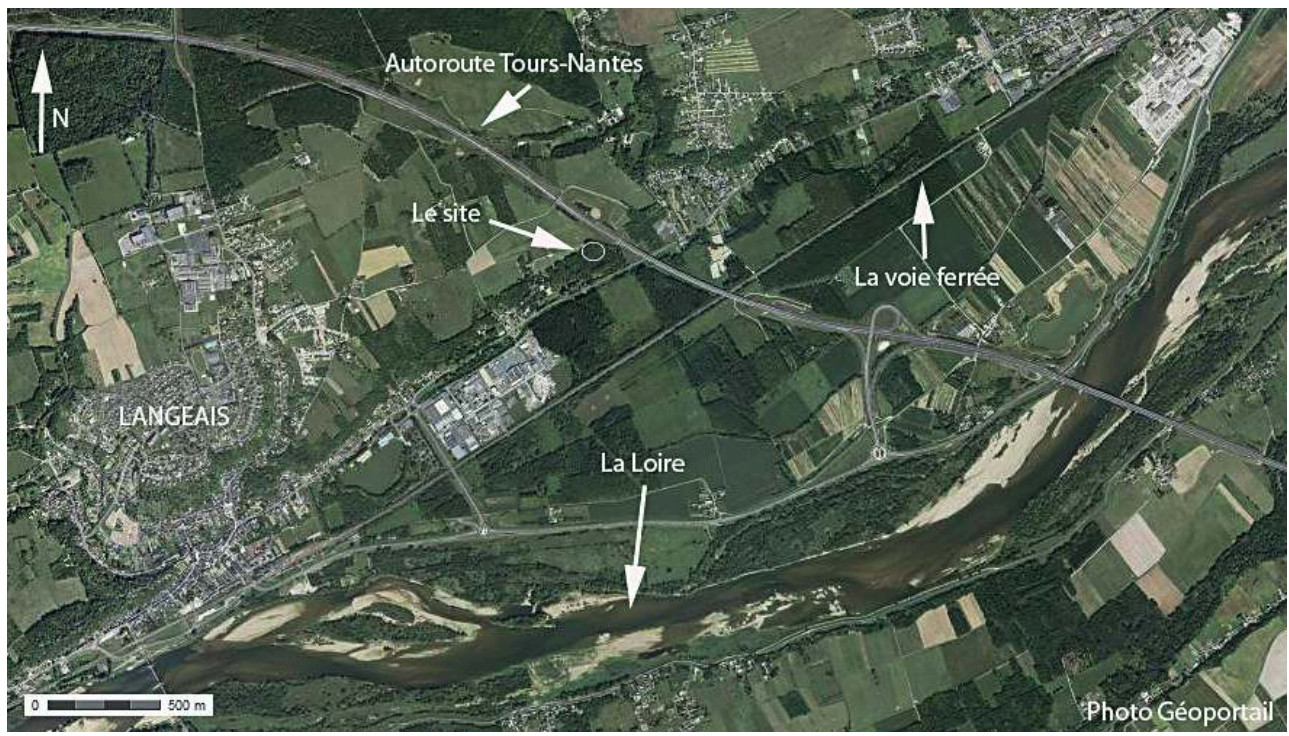

Figure 2 - La Roche-Cotard. Situation of the four locus of the site.

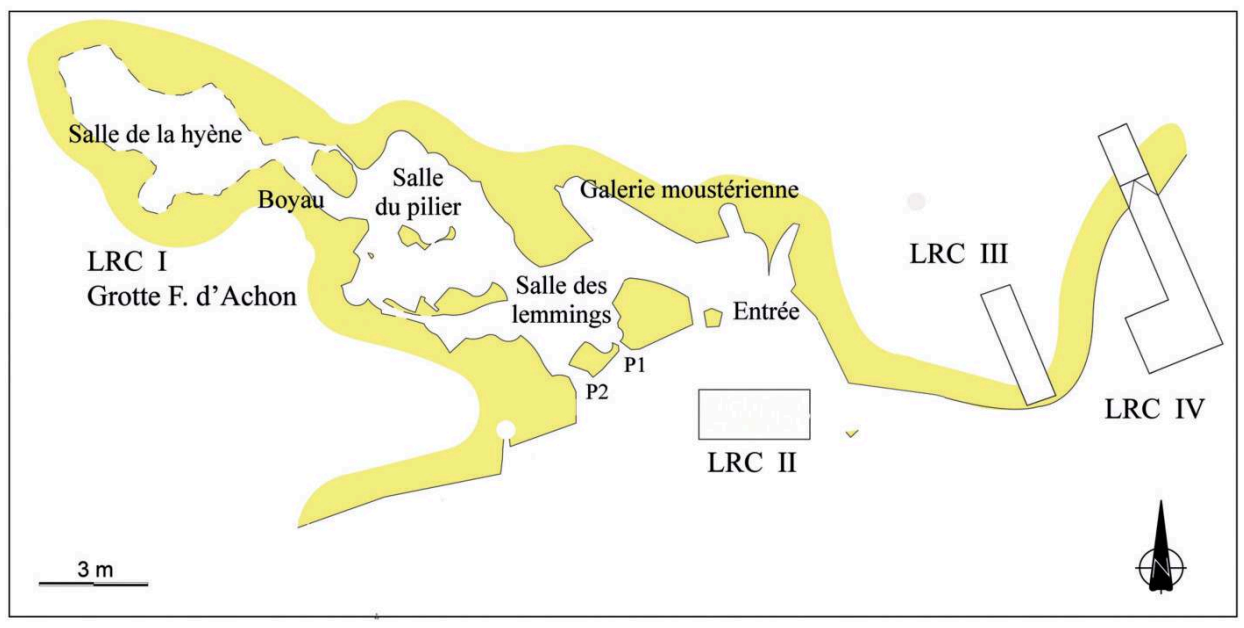

\section{2 - The various stratigraphic sequences}

9 For the purpose of the demonstration we want to do here, crucial for the dating of the finger flutings, we will present two of the different stratigraphic sequences, LRC I and LRC IV.

\section{1 - The stratigraphy of La Roche-Cotard I}

In 1912, François d'Achon with the help of his workers, emptied the cave in a few weeks to collect knapped flints and bones of large mammals (d'Achon ibid). In his publication, he gave a map of the cave indicating, roughly, the location of the different finds (fig. 3), with poor photographs of the excavated bones and knapped flints but, unfortunately, without stratigraphic section of the infill. 
11 When we resumed the excavations (1975-1977), a new map was done, which was taken up later by the topographical service of the Union of the Caves 37 (fig. 2) at the time of the 2008 excavations. We then excavated partly some remains of residual layers situated in altitude, and the sediments were analyzed.

Today, we can consider that in the first part of the cave, the stratigraphy is broken down as follows (fig. 4):

- A lower layer, whose thickness is difficult to assess due to the irregularity of the ground that rises very rapidly when one moves away from the entrance. It consists of very fine sandy sediment containing few bone fragments and lithic pieces of flint of very good quality for its capacity to be knapped and in excellent condition. This level has been dated by $14 \mathrm{C}$ in the Mousterian gallery to $38,060 \pm 940$ years (Lyon 7864) (table 1).

- A thick middle layer composed of sediment, which has the characteristics of an overflow silt of the Loire (Macaire in Marquet 1997). It contained the remains of large mammals, bovines, equine, deer, etc. (Byrne, Delpech, Prat in Marquet 1997) very strongly influenced by the action of hyenas (broken and gnawed bones), but absolutely no lithic industry. It was dated by $14 \mathrm{C}$ to an age over or equal to 38,400 (Gif 4447) in an alcove in the entrance of the cave and to $43,000 \pm 2,400$ (Lyon 6961) in the Lemmings Chamber. A remain of the middle layer was also preserved from the extraction of materials in 1846 and from erosion as it is, outside of the cave, protected at the bottom of a relatively deep small niche. A sample taken for OSL dating method has enabled to unearth a bone, currently being dated, and a very good flint flake (not the local flint that is damaged by frost) and very fresh. The latter element shows that it comes from the base of this middle layer as it incorporated this flake from the lower layer containing Mousterian industry. The $14 \mathrm{C}$ dating of the bone is not yet known but the OSL method gives an age of $72,600 \pm 6,000$ years (MFGI Budapest) for the sediment in that niche;

- An intact upper layer in very large remains that completely fills a corridor communicating between the Lemmings Chamber and the outside. One part is still in place and covers a remain of the middle layer; this set will be preserved. The nature of this layer is fundamentally different from that of the middle layer, very rich in cryoclastic elements; the fauna confirms a particularly cold climate episode while it was building up. A bone has been dated between 34,795 and 35,942 BC (Lyon 6962) by $14 \mathrm{C}$ and the sediment to $64,100 \pm 5,100$ (MFGI Budapest) by the OSL method. The difference between the dates obtained by the two methods comes from the fact that for almost all of the $14 \mathrm{C}$ dates in La Roche-Cotard, we are close to the limit of validity of the method;

Next to these remains found near the outside of the cave, there were others, more distant from the entrance:

- A 7 to $8 \mathrm{~cm}$ thick intact layer, not reached by d'Achon, in the northern part of the Chamber of the Pillar, is made of particularly compact clay that contained few rare angular fragments of bone, isolated teeth but also large amount of small fragments of cancellous bone. Only one knapped flint was found in this layer. The sediment is quite poor in pollen grains. A micromorphological blade shows the compactness of the sediment and the microstructure confirms that a significant packing has affected this layer dated to $47,500 \pm 3,000$ by $14 \mathrm{C}$;

- In the last available space of the cave, the Hyena Chamber, a thick filling was partially excavated by F. d'Achon who has collected a large number of large mammals remains, broken and eaten by hyenas, as well as an almost complete hyena skull. An equine tooth, forgotten by d'Achon, was found resting on the hardened surface that terminates the infill 
while the survey pit in the underlying layers did not yield any object. This tooth has been dated to $44,600 \pm 2,300$ by the $14 \mathrm{C}^{6}$.

Figure 3 - Map of cave F. d'Achon, drawn in 1912 by architect J. Froisson. The plan indicates clearly the limit of taken sediments extracted for the railway between Tours and Angers.

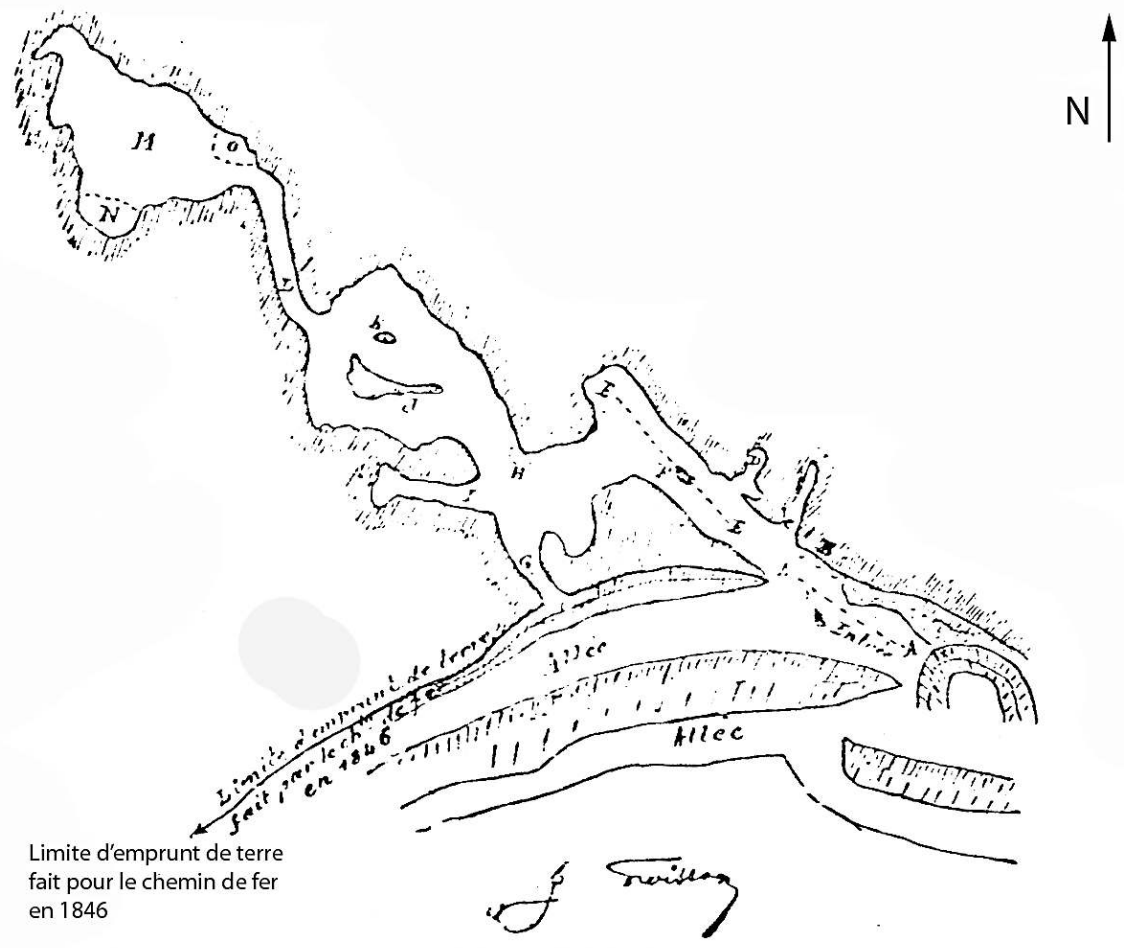

Figure 4 - La Roche-Cotard I. Stratigraphy of bits of archaeological strata.

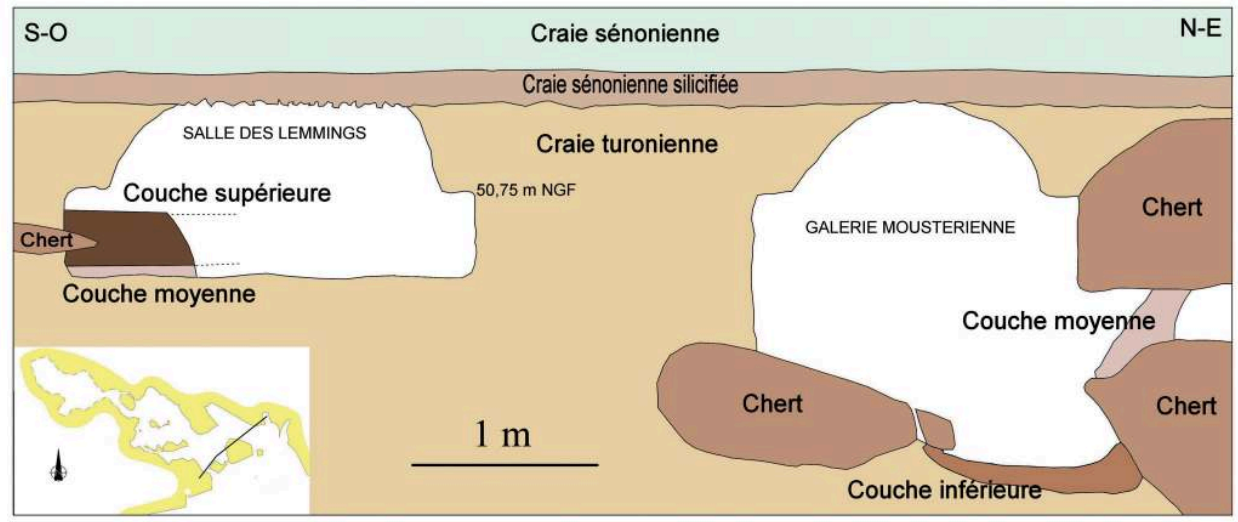

\section{2 - The stratigraphy of La Roche-Cotard IV}

The reopening of the excavation in 2008 was particularly motivated by the desire to continue a former test pit beyond La Roche-Cotard III, which had not reached the tuffeau chalk wall. A one meter wide trench then an excavation in a small cave-shelter discovered at the base of the wall helped to highlight a ten meters thick stratigraphy (fig. 5). 
The layers discovered are the result of various contributions: on the external side, some result from the overflowing of the Loire River (layers 10 and 11), others on the internal side are due to the dissolution of the limestone that form the substrate (layer 22) and, finally, the last ones, vertical and rich in frost-flaked plaques (layers 7-9) or mostly sandy-silt-clayey (layers 2-6) from the dismantling of the wall and the slope-washed layers from the plateau. Layer 22, the oldest, has been dated to $189,000 \pm 14,900$ years by the OSL method (MFGI Budapest). The layers of the middle part of the infill (c 12 and 13) have yielded some knapped flints, always very fresh and a few broken bones, sometimes burnt, rarely worked (incisions by flint, retouchers). Layer 12 has been dated by the OSL method to $86,200 \pm 6,500$ (MFGI Budapest), layers $13 \mathrm{~b}$ and $13 \mathrm{~d}$ of an age over 45,000 (Lyon 7862 and Lyon 7863). We shall return later to the interest of this thick filling.

Table 1 - Langeais. Radiocarbon dating and by OSL method of levels of the four loci of the site Roche-Cotard.

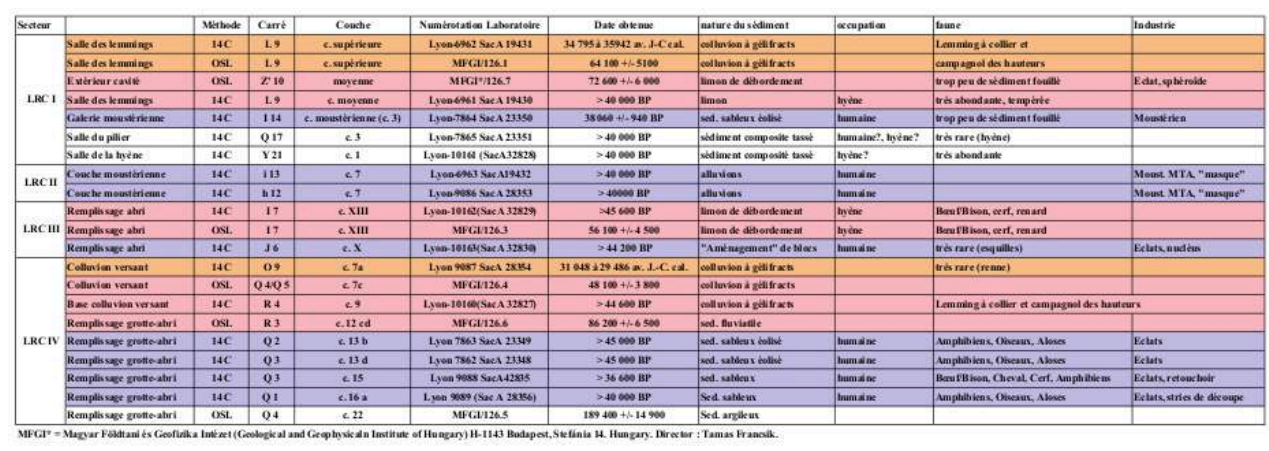

OSL MEASUREMENTS WERE MADE USING A RIS $\emptyset$ TL/OSL DA-15C/D AUTOMATIC READER WITH A CALIBRATED 90SR/90Y BETA SOURCE. LUMINESCENCE PURITY OF THE QUARTZ EXTRACTS WAS CHECKED USING INFRARED STIMULATION. BLUE LIGHT-EMITTINg DIODES (LEDS) WERE USED FOR THE OPTICAL STIMULATION OF QUARTZ FOR 40S, AT $125^{\circ} \mathrm{C}$. A SINGLE-ALIQUOT REgENERATIVE-DOSE (SAR) PROTOCOL WAS USED TO ESTIMATE EQUIVALENT DOSES WITH ILLUMINATION FOR 40S AT $280^{\circ} \mathrm{C}$ IN THE LAST STEP OF EACH CYCLE (WINTLE AND MURRAY, 2006). THE ADDITIONAL LAST CYCLE WAS INFRARED AND THEN BLUE STIMULATION WITH IRSL AND OSL MEASUREMENT RESPECTIVELY TO MONITOR THE PURITY OF THE QUARTZ GRAINS ON EACH ALIQUOT (THAMO-BOZSO 2013). MEASUREMENTS HAVE BEEN MADE BY DR. E. THAMO-BOZSO, SUPERVISED BY DR. G. TURCZI, REVIEWED BY DR. I. KOVACS AND APPROVED BY DR. T. FRANCSIK, DIRECTOR IN BUDAPEST, 2013. 
Figure 5 - La Roche-Cotard IV. Total stratigraphy of the locus. The upper part is north-south, the lower part is east-west.
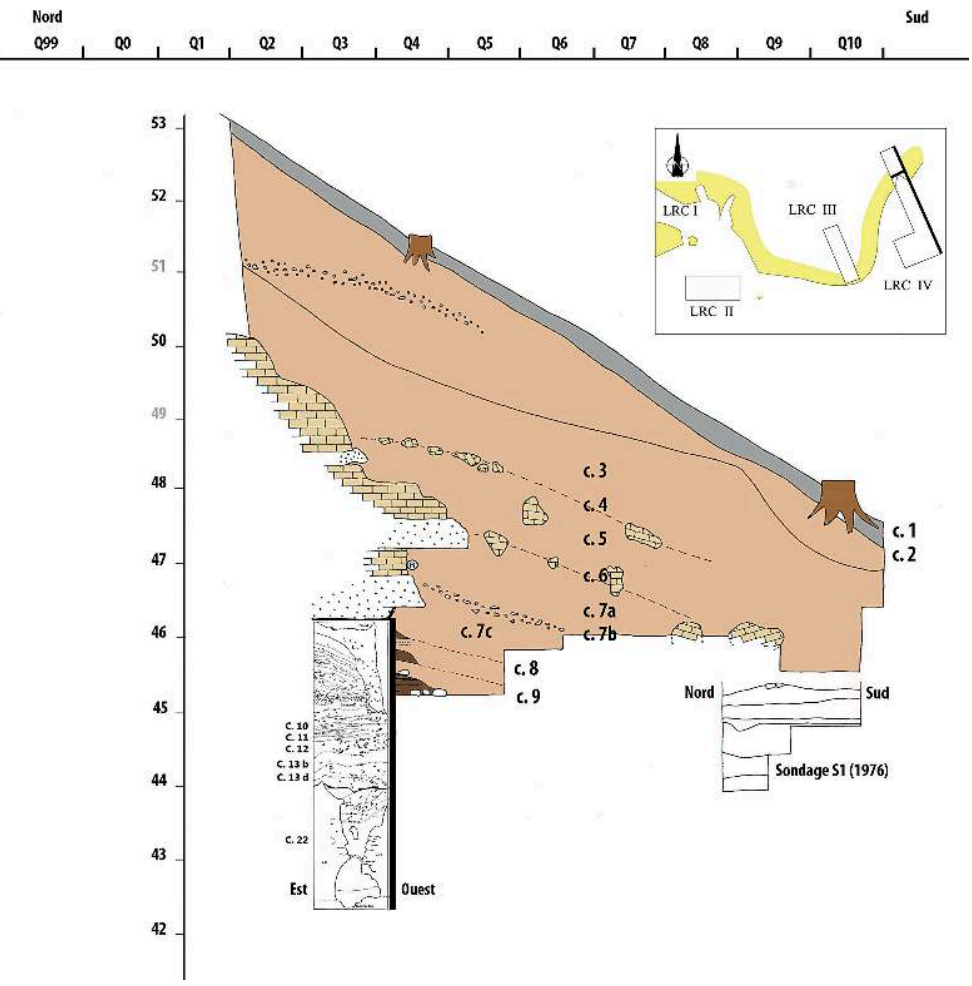

\section{3 - Geological context, site geometry and geomorphology}

16 A very particular geologic setting is at the origin of the formation of the main cave. This context covers three points (fig. 6): the nature of yellow tuffeau chalk of the upper Turonian, the presence within the chalk of huge tenacious siliceous masses (we will use the term "chert" for this material, almost impossible to knap), and finally the existence, at the base of the Senonian stage that is based on the tuffeau chalk and forms the ceiling of the cave, of a hard level, solid, under the shape of a highly silicified calcarenite.

If the extraction of materials in 1846 had not been done, we would have here, as we have upstream and downstream, a plateau ledge sloping progressively until reaching the surface of the modern alluvium of the Loire, and a convex slope in the upper part, concave at the bottom. The removal of soil completely changed this profile, making it very steep where the soil was removed with variations resulting from the presence of huge masses of chert at the level of loci I and III, where the removal of the material could not get as close to the edge of the plateau as in the east and the west. The impact study conducted for the A-85 motorway viaduct, now virtually built on the site (Rialland et al. 1995), revealed, through drilling, the existence of the flooded cliff and at the foot of it, ten meters deep, the remain of alluvial sediment of the Loire at the same height as that of LRC II. The profile, suggested by the test pits, done in the removal zone towards its eastern extremity, is quite similar to the one of LRC IV. It confirms the nature of this slope whose deposits are masking a flooded fossil cliff. 


\section{4 - Parietal traces in the d'Achon cave}

\section{1 - The parietal geological context}

cave is dug into the upper Turonian yellow tuffeau chalk (fig. 6), naturally soft even in the presence of sound rock. Exposed to the air, the chalk undergoes an alteration that, in the end, near the entrance of the cave, for example, causes the erosion and fall of a fine powder at the foot of the wall. This thin layer of altered tuffeau, intact, can easily be marked by the end of a finger without exerting pressure.

19 A very thin brown silt-clayey film, homogeneous, very soft too, a few millimetres of maximum thickness, covered the wall, fitting perfectly its shape (fig. 7). Originally, it must have covered the wall completely, today it is lacking locally for various reasons: scratches of cave animals (the material remains in the protected concave parts of the wall), finger traces or various instruments (one scraping shows a recent graffiti) and through the effect of gravity in the case of very thin layers (very localized) on the wall, etc. This silt clay film is still very fragile.

20 The analysis of the clays by X-ray diffraction of the material taken from the Chamber of the Hyena shows that it cannot come from in situ weathering of the tuffeau chalk (Touron, Bourges 2012). Besides, its thickness is not constant: it can be 3 to $4 \mathrm{~mm}$ thick or form lumps that are still stuck in the tuffeau.

\section{2 - The traced panels of La Roche-Cotard}

\subsection{1 - Overview of the north wall of the Chamber of the Pillar}

21 The north wall of the Chamber of the Pillar has been the subject of a photographic coverage by Y. Egels (18 $\mathrm{mm}$ lens, details in $55 \mathrm{~mm}$ ). The photographs allowed obtaining a 3D representation of this part of the chamber (fig. 8). A first process was carried out with the 123D Catch software.

The main characteristics of the wall appear well on the photo:

- The ceiling formed by the base of the Senonian is highly heterogeneous;

- The shape of the Upper Turonian tuffeau chalk wall shows the highly homogeneous constant texture of the chalk, if one disregards the cherty masses, from the cave entrance to the Hyena Chamber. This wall carries the traces of the history of the cave;

- Above the $g$ line, the tuffeau wall is partly covered with a thin film ( 3 to $4 \mathrm{~mm}$ maximum) of a silt clayey reddish brown material;

- At the base of the section, the horizontal level formed by the chert slabs is visible;

- Under the slab of chert and the accompanying decalcification clay layer, there is the tuffeau chalk.

\subsection{2 - The four main panels of finger tracings}

On the walls of the cave still covered by silt numerous traces of anthropogenic origin can be seen. We will limit ourselves here to present the four main panels, easier to read and trace. 


\subsubsection{1 - The circular representation panel} may locally reach 3 to $4 \mathrm{~mm}$. At the bottom of the traced line, the colour of the material is very different from that of the silt: it is the surface layer of the tuffeau chalk that has been altered. It has remained in place, trapped under the silt. The circular structure is composed, on the left, of two sub-parallel lines and, on the right, of four lines done at the same time by the same hand. The two lines on the left end by two circular impacts at the bottom, probably from fingers, identical to four or five other impacts that are found on the bottom left of the circular figure. Similarly, the sub-horizontal line of the base of the representation appears to come from a nearby impact but distinctly separated from one of the two impacts on the left. The four "parallel" lines on the right are not connected to pressing on the walls, at none of the extremities. A priori, the course of the four fingers is downward. Logically, the two lines on the left should be ascending and end with a strong impact like in the lower line that starts with a mark of the same type. The technical interpretation test (fig. 10) offers, for each line, the direction in which it could have been done. Hesitation is possible regarding the two curved traces on the left. At one of their extremities, there is a large punctiform impact that seems to result from a finger pressing strongly on the silt. It would seem more logical to see this mark at the start of the line but then it would be an ascending line, which does not seem to correspond to a natural movement of the hand and arm. The alternative is that this strong pressing ends the line and in this case, the movement that makes the line from the top down is an easy natural movement to achieve. A subsequent analysis of macrophotos may be able to help decide between the two possibilities. 
Figure 6 - La Roche-Cotard I. The ceiling of the cave is made of a strongly silicified biocalcarenitewhose fossils indicate Senonian. The walls show soft «tuffeau chalk» of upper Turonian. Levels of «chert» are visible inside Turonian.

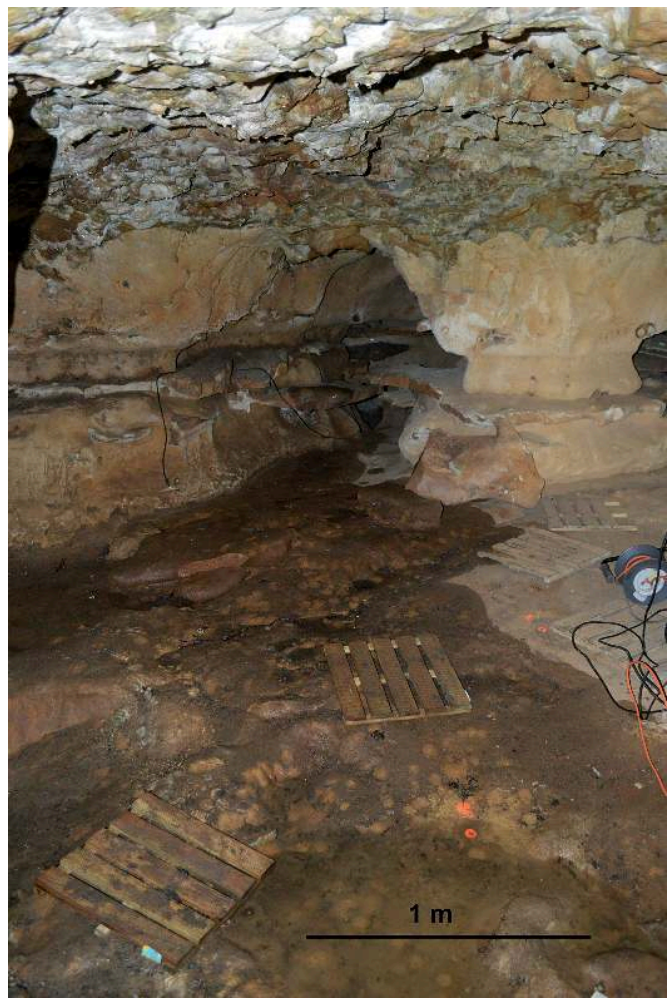

Figure 7 - La Roche-Cotard I. In " la salle du pilier ", the wall is covered with a silty clay which is no present on raised relief and cut in by numerous animal grazings.

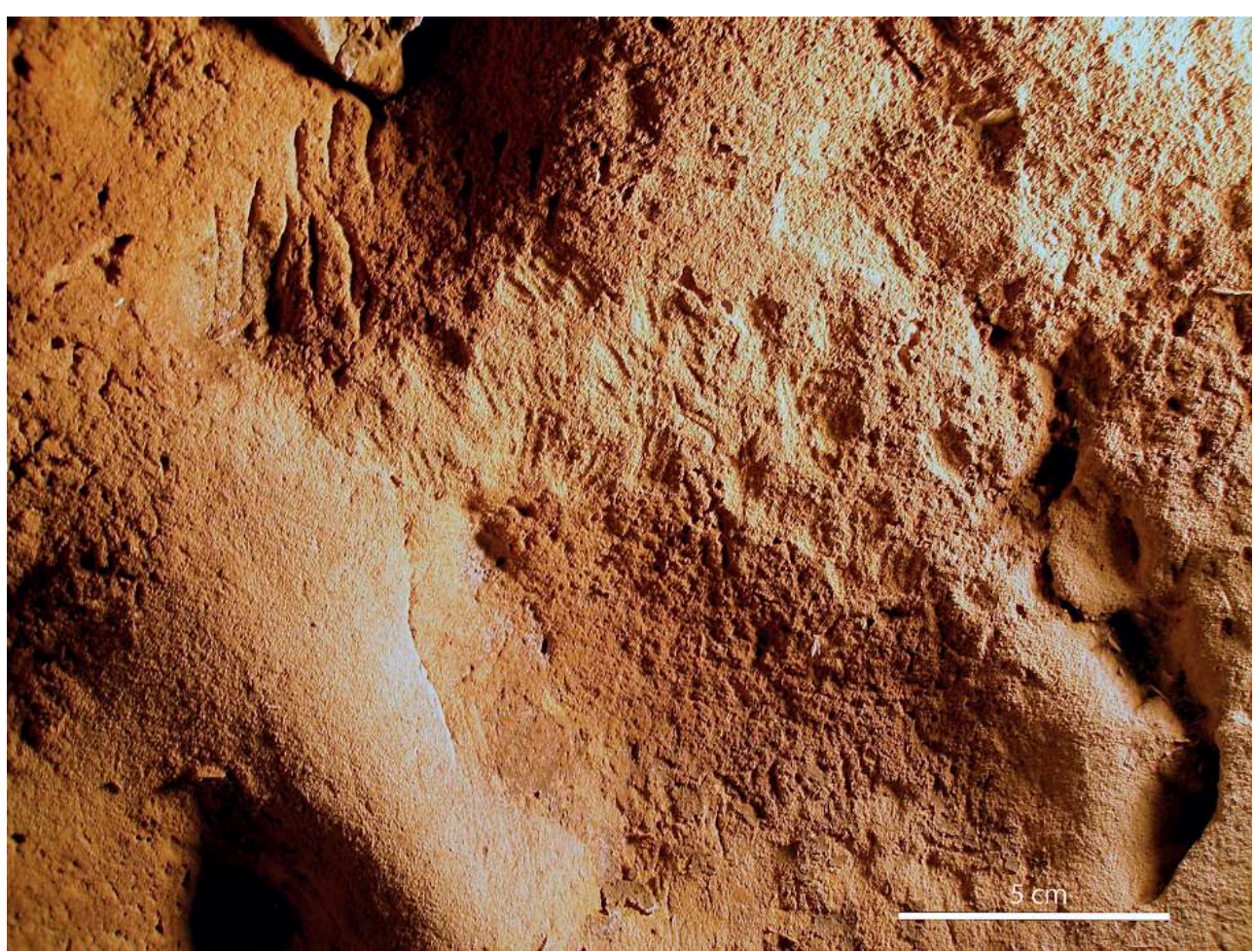


Figure 8 - La Roche-Cotard I. La salle du pilier. 3D view of the alcove whose wall has markings panels(photo Y. Egels). On left, the situation of that alcove in the room. On right, the position of the different panels. a. Limit between senonian cieling and turonian wall. b. «Chert». c. Lower «chert» level. d. Triangular panel. e. Rectangular panel. f. Punctuation panel. g. Upper limit of the wall which has been dissolved during a phase before occupation of the cave by man.

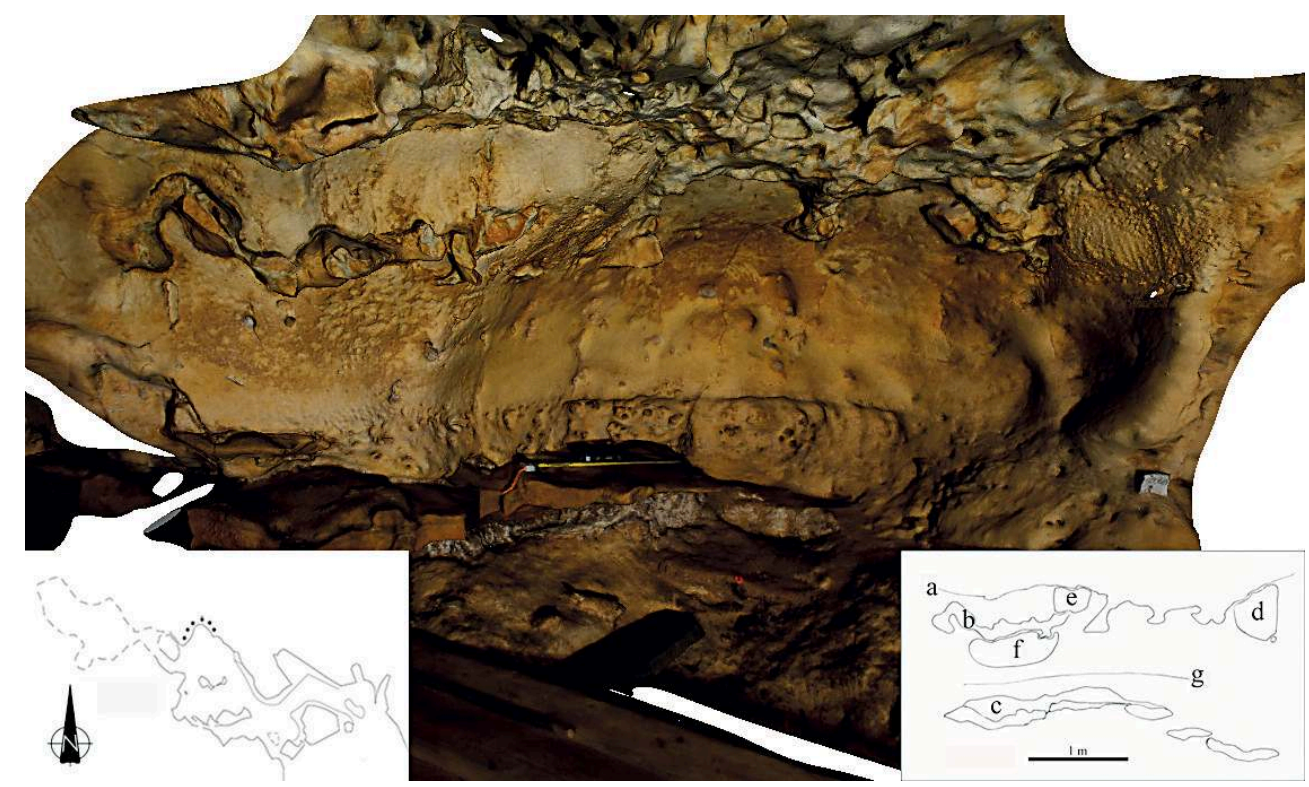

\subsubsection{2 - The triangular panel}

This panel is shown in figure $8 \mathrm{in} \mathrm{d}$. It has roughly the shape of an isosceles triangle (fig. 11), whose base, located at the top, measures $44 \mathrm{~cm}$. The height, axis of symmetry of the triangle, measured up to the centre of the small cherty block located on the opposite corner to the base is $30 \mathrm{~cm}$. The panel is located at the top of the tuffeau chalk wall just below the ceiling. The side of the isosceles triangle, on the left, is well marked by a relief a few centimetres in height; the other short side coincides with a kind of advanced relief of the wall, an almost vertical rim in its upper half, significantly more oblique to the left, in its lower half. On the apex of the triangle, on its axis of symmetry, the small chert ,slightly oval section, is in its natural position; it sticks out from the tuffeau, and its section is $45 \mathrm{~mm}$ long and $30 \mathrm{~mm}$ wide.

The triangular panel is covered with tracings made with the finger or using an instrument in the shape and size of a finger (we'll talk then of digital tracings), nearly parallel, perpendicular to the base of the triangle. These lines are a little less visible on the right than on the left and centre parts. They preserve, in the panel on the small left side, three silt triangles that continue the sediment film still in place below the panel (fig. 12). Silt from the leftmost triangle, the largest, has a thickness of about 4 to $5 \mathrm{~mm}$ but this may also include a portion of the altered tuffeau film that is trapped below. The following triangle, located near the middle of the side of the triangle, is formed by roughly $3 \mathrm{~mm}$ thick silt. Finally, a third triangle is visible, more to the right; the thickness of the silt is weaker than on the previous two and is also smaller.

Photogrammetry and processing in coloured image, done by Y. Egels (fig. 13) show equidistance of the order of $1 \mathrm{~mm}$ between the curves. The relief is well perceived at the level of the triangles, especially on the leftmost, where we can see the clear asymmetry between the two main sides of this preserved silt triangle. The hollow parts appear in orange and red, the raised parts are green and blue. The shape of the two 
"synclines" that frame the large triangle suggests that the operator took care in the preserving this area.

The interpretive tracing (fig. 14) shows two large parallel axial crests ( $\mathrm{d}$ and e) separating the panel into three parts: the left portion has the three residual silt triangles ( $\mathrm{a}, \mathrm{b}$ and $\mathrm{c})$; a rectangular central part forming an axial strip extends downwardly with the chert block with oval section; finally, the right side still shows finger tracings, slightly less readable than others, but a correctly oriented lighting allows observing these traces until the end of the extremity of the right side of the triangle.

The examination of the left of the panel reveals a certain rhythm in the succession of the finger tracings and the three residual triangles (fig. 14): completely on the left, three parallel digital tracings (1,2 and 3) pass on the left of the large silt triangle (a); then a group of three digital tracings $(4,5$ and 6 ) lead between the previous triangle (a) and the following (b); between $b$ and c, a new group of three lines (7, 8 and 9); finally, for this first part of the panel, a group of three parallel lines $(10,11$ and 12) is placed between the latter triangle and the first of the two axial crests. These ( $d$ and e) are clearly separated by a group of three digital markings $(13,14$, and 15$)$ which are exactly parallel. They form much stronger reliefs than those separating the preceding adjacent finger tracings. In section, the width and height are of the order of 4 to $5 \mathrm{~mm}$ in their median part. These two crests terminate downwards by two wider parts where a larger amount of silt was preserved. The strip formed by the two crests and the three lines that clearly separate them, constitute a kind of symmetry axis of the isosceles triangle. To the right of the second crest (e), the digital tracings are less visible and the same reserved triangular areas than on the opposite part are not found. However, we can count 8 or 9 lines on the right of the crest $(16,17$, etc.) and then two long lines that seem to go down at least to the level of small oval section chert. In general, it does not seem possible to make assumptions about the order in which the different tracings were made. However, even if there are no observations to justify it, it is not clear how these plots could have been achieved otherwise than from the top down. Further to the right, the silt coating starts again, locally granular, with gaps. 
Figure 9 - La Roche-Cotard I. Panel with circular form in « la salle du pilier ».

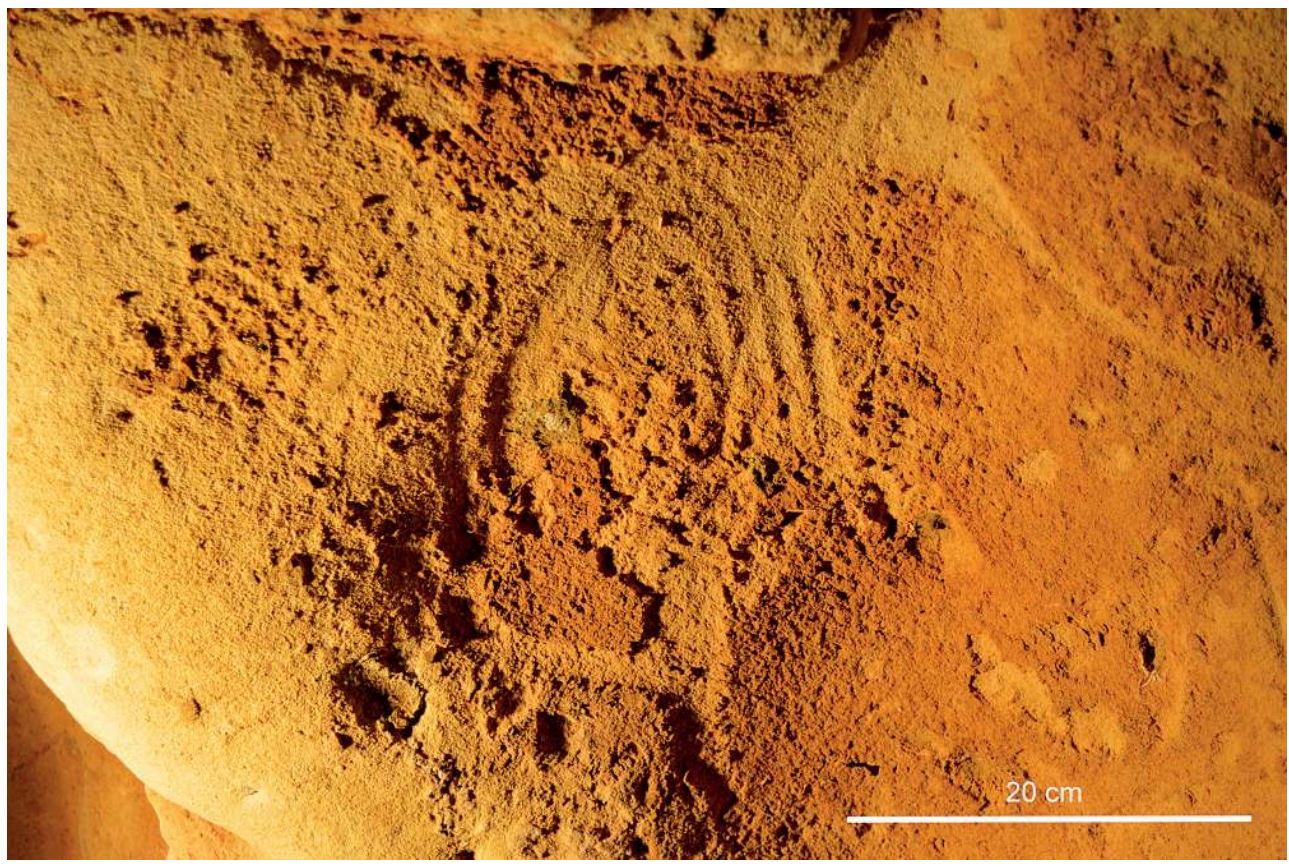

Figure 10 - La Roche-Cotard I . Interpretative essay of the panel with circular form in « la salle du pilier ».

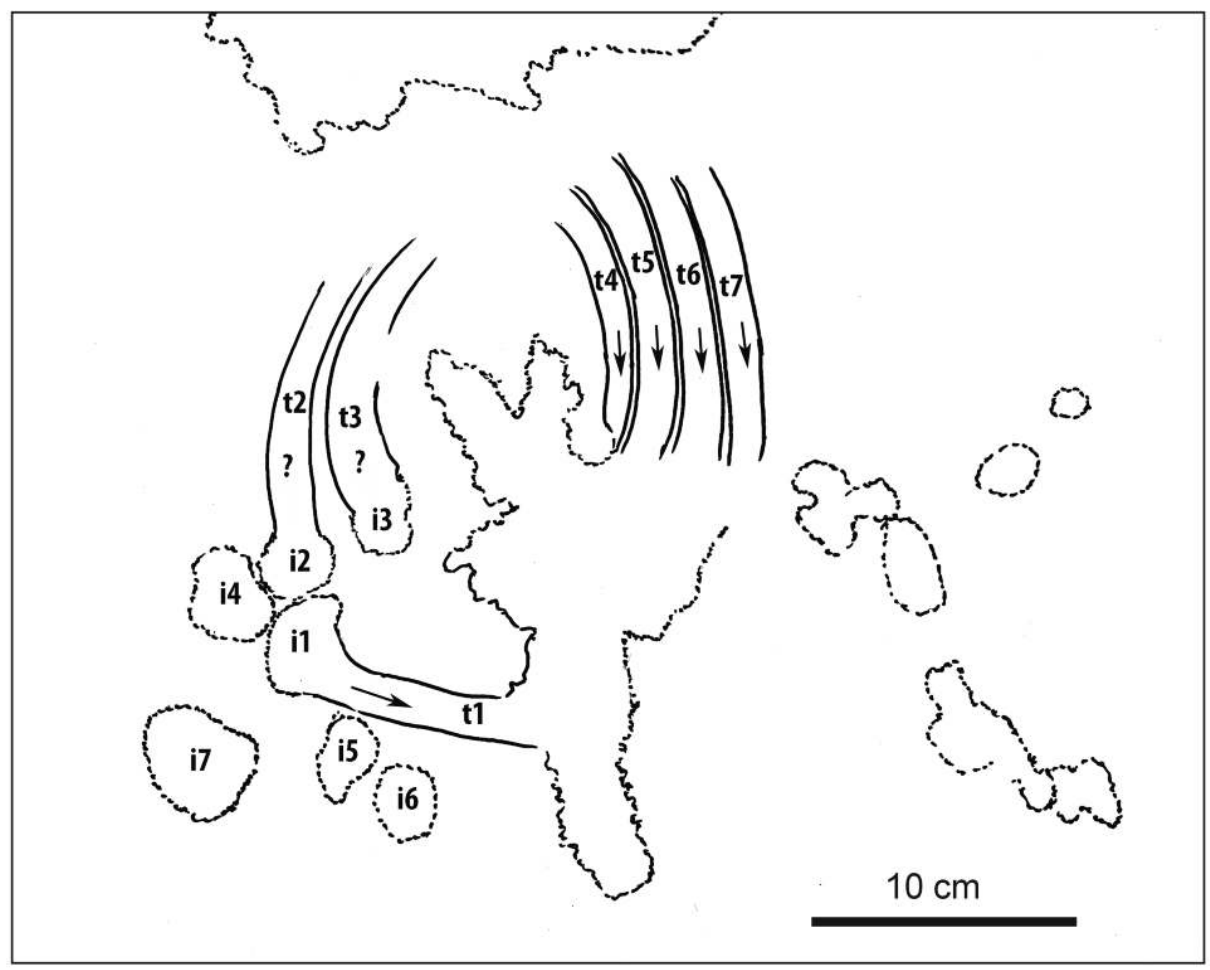


Figure 11 - La Roche-Cotard I. Triangular panel (fig. 8d).

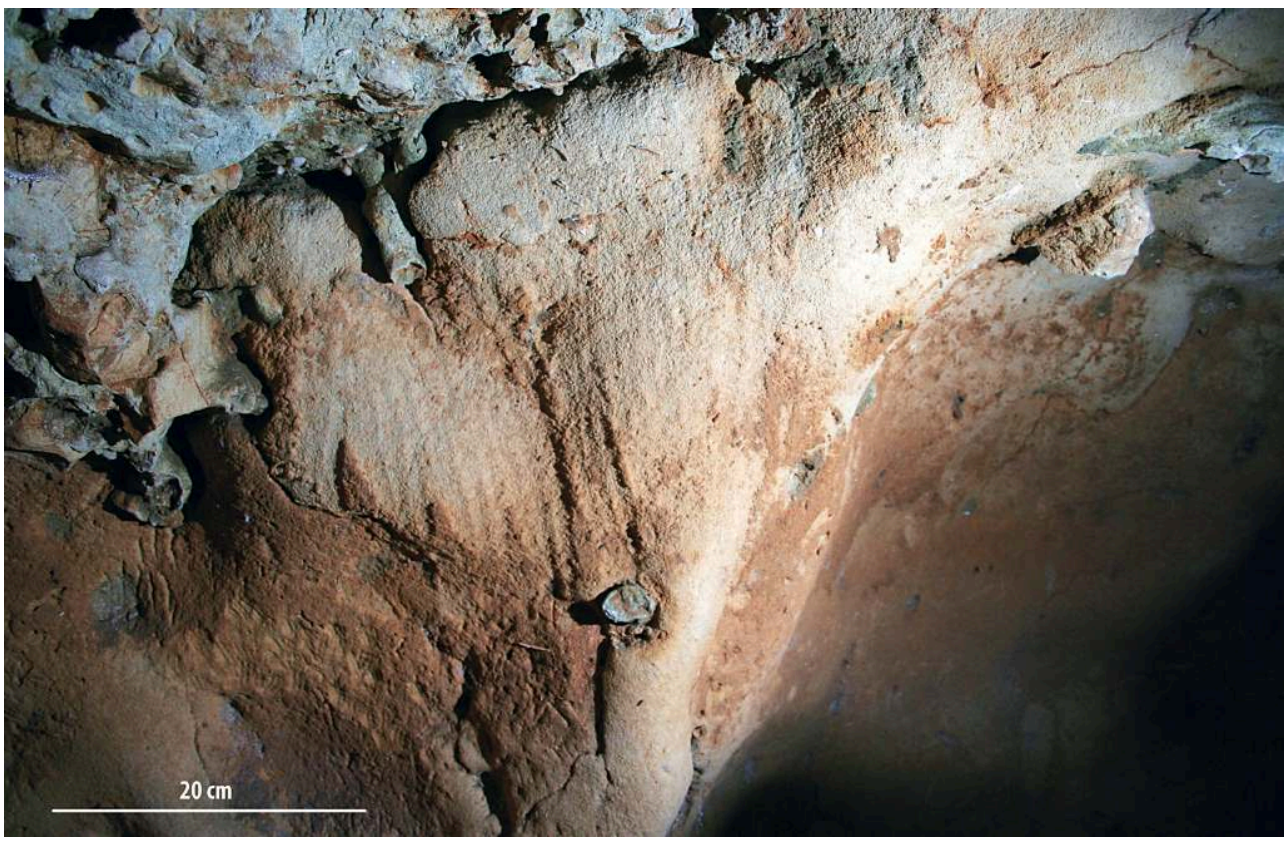

Figure 12 - La Roche-Cotard I. Triangular panel. Detail showing reserved parts (three triangular parts and two narrow parallel lines).

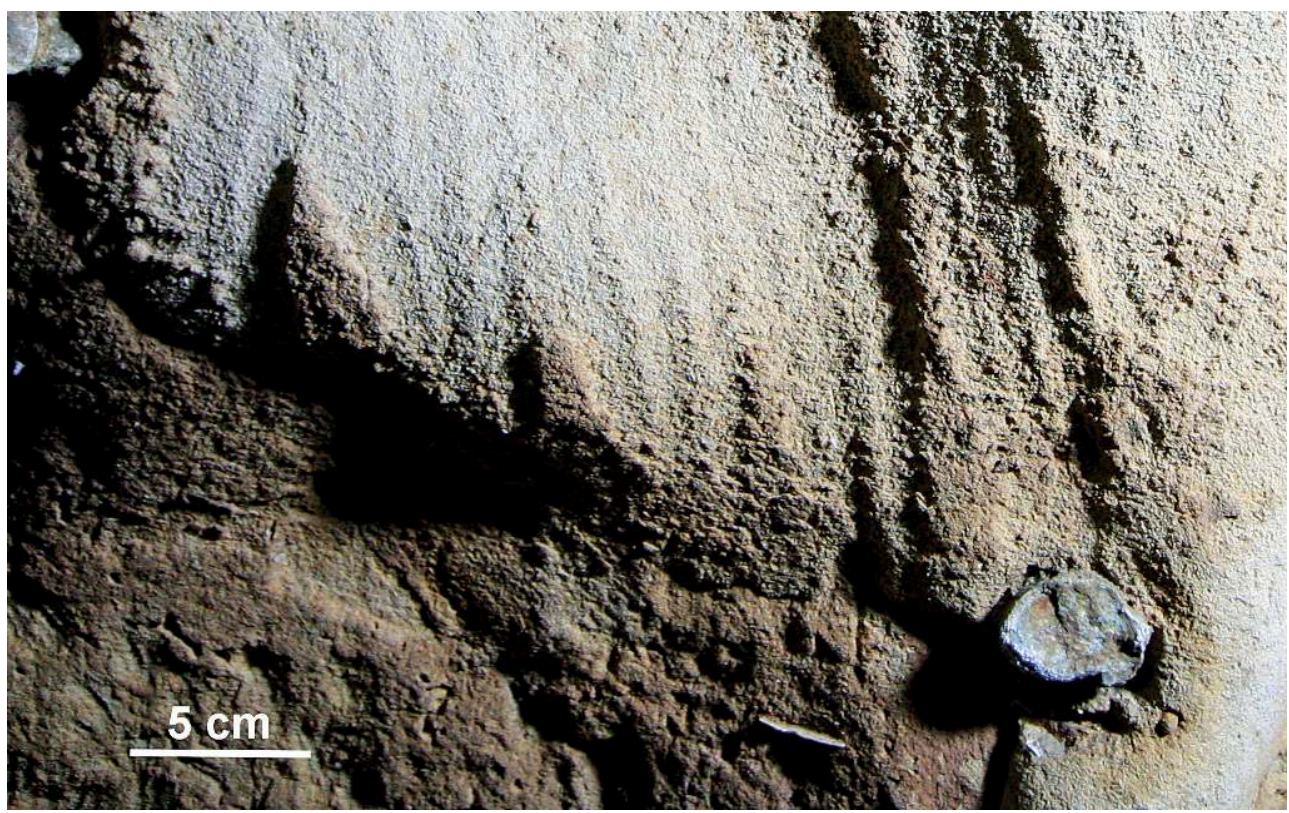

\subsubsection{3 - The rectangular panel}

This panel corresponds to the area e of figure 8. Substantially rectangular in shape, it ends, to the right, in a narrow horizontal wall strip of tuffeau chalk located between the ceiling of the chamber and a long cherty roughly horizontal ridge (below). As with the previous panel, there is a gap at the contact of the Turonian wall and Senonian ceiling. Its location, just below the contact, can explain, as in the previous panel, its good conservation, in height, protected from the passage of furry animals (fig. 15). On the bottom right, part of the panel is free of finger traces (or of the spatula shaped 
instrument that could also have been used). On the bottom left, the traces are stopped by an overhang or the beginning of the cherty ridge.

The whole group is $35 \mathrm{~cm}$ long and $25 \mathrm{~cm}$ high on average. It is not vertical but slightly overhanging, its mean plane forming an angle of about $15^{\circ}$ from the vertical.

The panel shows 27 to 30 traces with concave section, roughly parallel, almost perpendicular on the long side, forming a slight fan opened towards the top. However, it has some irregularities in the lines with bifurcations, out of which three are facing down and two or three in the opposite direction. All the traces have about the same reduced depth. One may wonder if this is not only the deepest part of the lines, the top part having been removed by gentle erosion.

There is no brown silt on the composition, so it is impossible to say that it was covered by it as in the previous two panels. Indeed, the remains of the reddish brown material still present on both sides of the panel may have been set up by another process than the one that enabled the wide covering of the lower areas. However, it is noted that it is at the same altitude as the triangular panel and that logically, if the silt film was implemented through a double capillary and drying phenomenon, it should also have existed at the location of this panel.

\subsubsection{4 - The dots panel}

It is represented by $\mathrm{f}$ in figure 8 . It is located under the chert ridge we used to locate the rectangular panel (fig. 16). It belongs, like the first two, to a wall covered by the brown coating. In this area, the silt covered the entire parietal area, but in its lower part, it was probably removed by repeated friction. Underneath, the deleted strip of coating is quite narrow and widens largely on the right. The boundary between the area with the brown silt coating, above, and that, at the bottom, which is free of it, is very clear because the brown colour contrasts significantly over the colour of the tuffeau. However, the transition is gradual as if the friction was progressively milder upward. Wherever the silt coating is present, roughly circular dots, $2 \mathrm{~cm}$ in diameter on average, were observed. The bottom of the dots shows the tuffeau chalk nearly flat everywhere: there is no impact strong enough to slightly cut into the tuffeau. Under the upper chert, the thickness of the silt layer, of the order of 3 to $4 \mathrm{~mm}$, is maintained until $25 \mathrm{~cm}$ lower; then it decreases steadily until it disappears completely. Some dots are well individualized, well separated from each other, especially on the left. However, on the right, the dots are always perfectly discernible, often contiguous and may even present an intersection (fig. 17). Towards the bottom, in the middle, a group of seven to eight impacts seems recent. 
Figure 13 - La Roche- Cotard I. Triangular panel. Detail. Photogrammetry. Treatment in color (Photo \& treatment Y. Egels). Orange and red parts are " synclinal », green and blue parts are " anticlinal " parts.

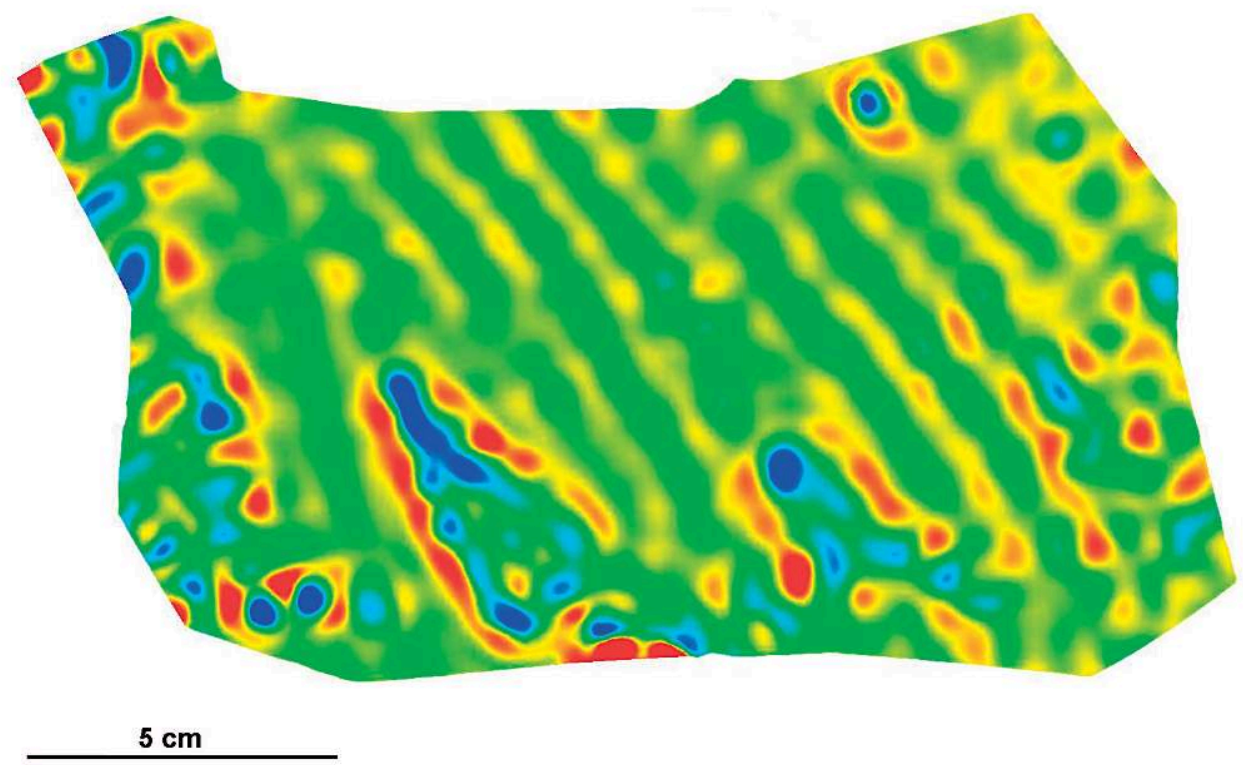

Figure 14 - La Roche-Cotard I. Triangular panel. Interpretative essay.

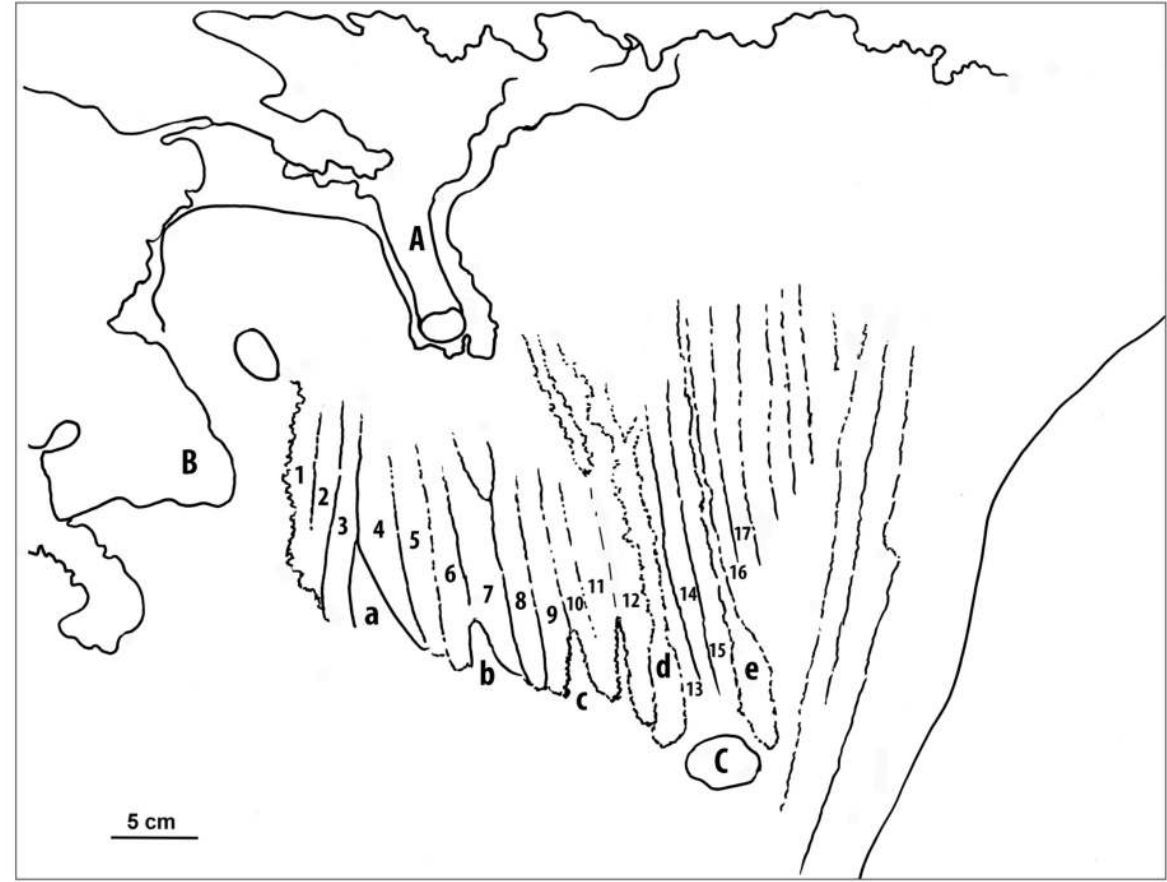


Figure 15 - La Roche-Cotard I. Rectangular panel (fig. 8e).

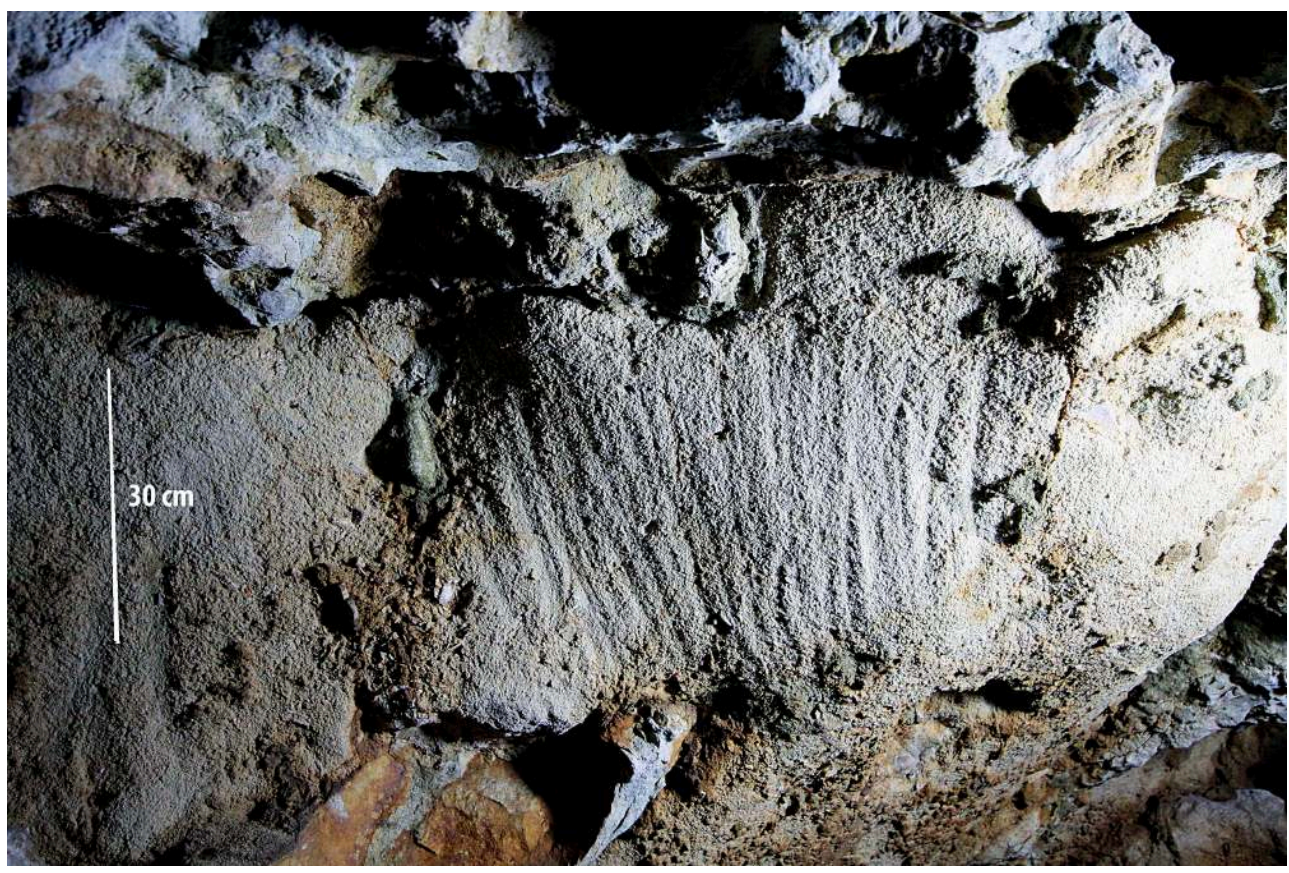

\subsection{3 - Technique of the making of the tracings}

37 This aspect of the study will be the subject of further research. For the three panels, circular, triangular and rectangular, it seems obvious that the traces were done with fingers rather than with a tool. As for the dot panel, unlike the previous ones, the lines seem to have been done with an instrument rather than a finger (thumb?): Indeed, the form of the dots is roughly circular, but some impacts have shapes with part of the contour rather straight. Moreover, for the elongated lines, we have offered, on interpretative sketches, proposals for the direction of the movement.

\subsection{4 - Alteration of traces}

\subsubsection{1 - The triangular panel}

Under the latter, the wall forms a vertical descending rim, another is located a little more to the left. They shape a concavity in which the brown silt is preserved, showing fine scratches, close together (fig. 7). On both convexities, the brown coating is not preserved. We make the same observation on all the parts in relief on the lower half of the wall of this area of the Chamber of the Pillar, while in the hollows, the silt is preserved. This erosion of the silt coating is attributable to the repeated passing of the medium-sized or large vertebrates who visited the cave.

39 Furthermore, we have noted a lesser sharpness of the digital tracings on the right side of the triangular panel. They have therefore been eroded but this cannot be due to the passing of animals. We can also wonder whether, in this chamber, there were originally many more panels with lines than those we see and describe today. In particular, on the north side of the pillar that gave it its name, another broad concavity facing that of figure 8 and on which, although devoid of any silt coating, highly covering digital tracings are still detectable. As to the cause of the very soft erosion that affected some 
lines, only one is possible: the flow of air against the wall of the cave. If these lines are indeed 40,000 years old or more as we propose, such duration appears sufficient to observe detectable wind erosion.

\subsubsection{2 - The rectangular panel}

simple: the parallel lines are so tight that the entire brown coating was removed when tracing them. These lines have also affected the alteration coating of the tuffeau chalk as they are marked in the thickness of this coating today. The only certain alteration is the natural superficial alteration of the chalk.

Figure 16 - La Roche-Cotard I. Panel with punctuations (fig. 8f).

\section{3 - Red pigment stains}

During their mission in July 2009, P. Paillet and E. Man-Estier (Man-Estier, Paillet 2009) identified in the corridor that leads to the Chamber of the Hyena, $280 \mathrm{~cm}$ from the end of the corridor, several stains of red ochre on the wall (fig. 18). The first one, well visible, is substantially circular in shape, measuring several centimetres in diameter. The pigment was deposited on the hard surface of an elongated cylindrical chert freed from the tuffeau chalk by differential erosion. The second stain, on the same chert, a few centimetres from the first one, is much less visible and more faded. Finally there is, but this time on the surface of the tuffeau chalk, a third trace of red pigment, less faded out. It has a half-circular shape $2 \mathrm{~cm}$ in diameter. They remain very difficult to observe in the upper part of a small niche that is at ground level in the corridor.

There is, in the same corridor, but on the other side, on the southwest side, a fourth ochre stain (fig. 19). It is situated two meters from the eastern entrance of the corridor in close proximity to a large crack that the phenomenon of dissolution has expanded to reach $5 \mathrm{~cm}$ wide and $18 \mathrm{~cm}$ high. Approximately circular, it measures just over a centimetre in diameter. It was probably partly erased due to repeated passing (traces of horizontal tearing off close by).

\section{5 - Many sites have yielded finger tracings}

If finger tracings are defined as a modelling done with the fingers on a soft surface (clayey or consisting of altered limestone of the moonmilk kind) that changes the appearance of the surface by a simple ribbon-shaped smoothing (Lorblanchet 1995), more than 65 sites with this kind of "decoration" are listed worldwide. Bednarik (1994) and Sharpe (2004) have proposed criteria for distinguishing the origin of these parietal marks other than human, done with a finger or any tool. According to publications, digital tracings are spread over at least 34 sites in Europe, including 27 in France and 7 in Spain, about thirty in Australia (listed in the "Parietal marking project" - Bednarik 1986, 2014), two in New Guinea (Ballard 1992) and two in the Americas: in Chile (Van Hoek 2011), in the Dominican Republic (DuVall 2010). 
As for the chronological position, according to von Petzinger and Nowell (2011), out of the 27 French sites, examples spread from the Aurignacian to the Magdalenian (dating based on stylistic and radiochronological criteria). A Bronze Age site discovered in 1989 (Aujoulat, Chevillot 1989) is being studied at the Fraux Cave (Petrognani et al. 2014).

Concerning the shapes, figurative or not, the typology proposed by Sharpe and Van Gelder (Sharpe, Van Gelder 2004, 2005) retains two variables: whether the author used one or more fingers to make a line, and if the author was moving or not while tracing the line. For further study, we will need to compare the finger tracings of La RocheCotard with other contemporary or related sites by their morphology such as BaraBahau, Aldene, Rouffignac caves, etc.

\section{6 - The dating of these traces}

As previously noted (Lorblanchet 2008; Man- Estier et al ibid..), there is no doubt that these lines are a human work done with the fingers or with a tool whose end would most likely be a different shape for the lines and the dots. Similarly, the red traces in the corridor cannot be due to the heating of the wall by a flame which would have given a different colour, rather brown. Here, the red is relatively bright and can only be due to ochre possibly mixed with another substance. The age of these lines? We will not be able to get a direct dating for the latter. A particularly thin white film exists on the surface of some natural clay deposits clinging to the wall. Only the contextual indirect dating elements will be available. Thus, we will turn to the results of $14 \mathrm{C}$ dating and OSL method. But first we will show that the geometry of the deposits of the four loci of La Roche-Cotard is a decisive contribution in terms of the approach to the age of the occupation of the cave by Neanderthals.

\section{1 - The geometry of the deposits}

\subsection{1 - F. d'Achon's observations}

In his article (d'Achon ibid.) published a year after the discovery of the cave, F. d'Achon noted: "...considerable removals of soil were taken in this part of the slope of the Loire, between Cinq-Mars-la-Pile and Langeais, at different times. These removals correspond initially to the time of the containment of the Loire and above all, in 1846, to the construction of the embankment of the Tours-Nantes railway that crosses, in this part of the course, the meadows of Langeais. The trace of these works can be seen on the limestone rock that forms the hillside of the valley where the remains of mine blows, pick and regular stone cutting are still visible." F. d'Achon continues: "The workers have stopped their excavation work in the park of La Roche-Cotard, below the entrance of the cave and have likely eliminated there, as elsewhere, numerous bones and knapped flints, which passed unnoticed at the time due to the lack of interest attached to them." The inventor of the cave finally added about the discovery: "The cave entrance was obscured by landslides and was visible on the outside only by the opening of a burrow. Inside, behind these masking sediments, it was filled up 30, 40 or 50 centimetres to the vault " (d'Achon ibid.). A photograph, taken shortly after the beginning of the excavations at the time still shows a portion of the soil that concealed the entrance of the cave, significantly reduced compared to the original mass. 
Figure 18 - La Roche-Cotard I. Two red ochre stains in a niche in the tunnel which is situated between «la salle du pilier " and " la salle de la hyène ». Above and on left, localisation of the niche with three punctuations.

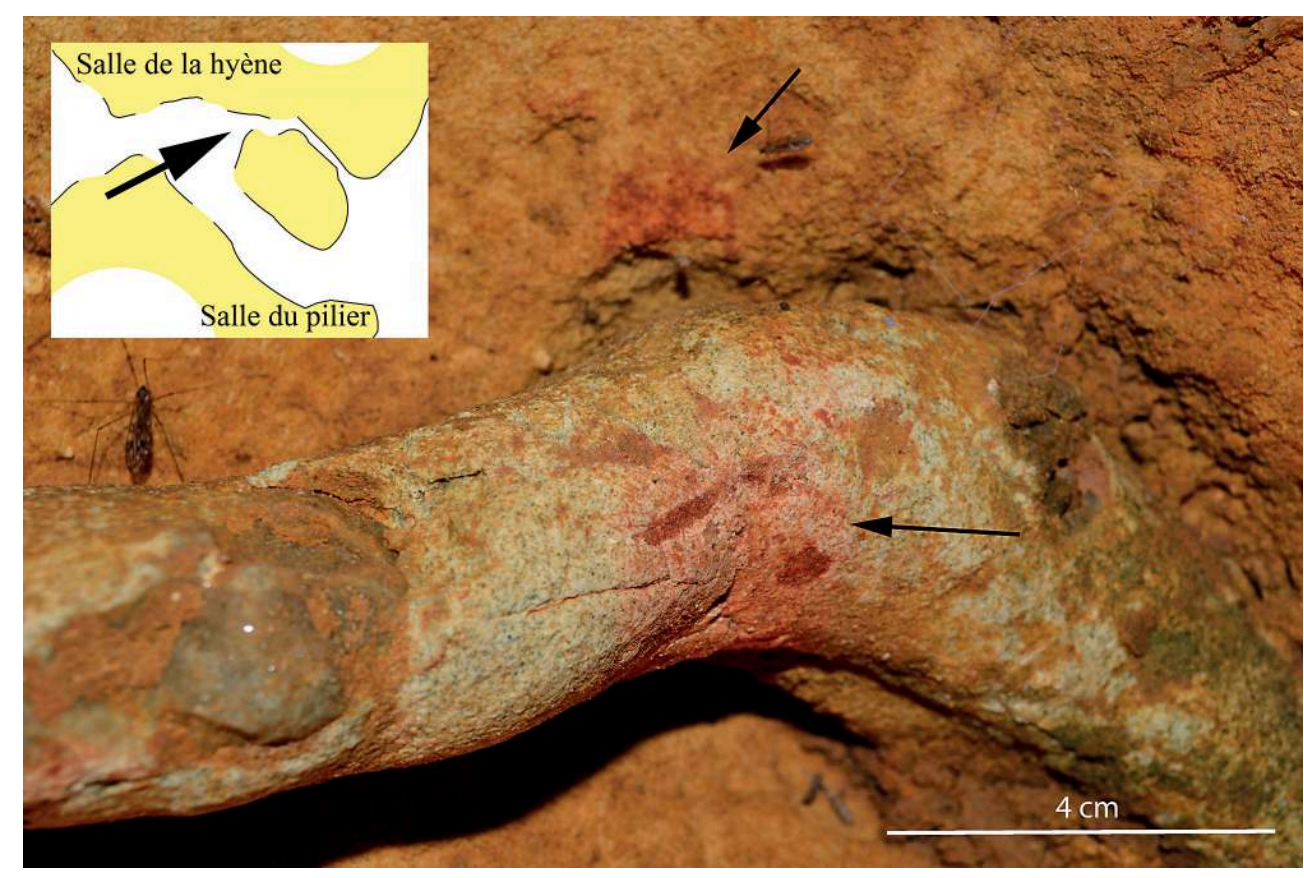

Figure 19 - La Roche-Cotard I. Red ochre puncture and its localisation in the tunnel which conduct to « la salle de la hyène ».

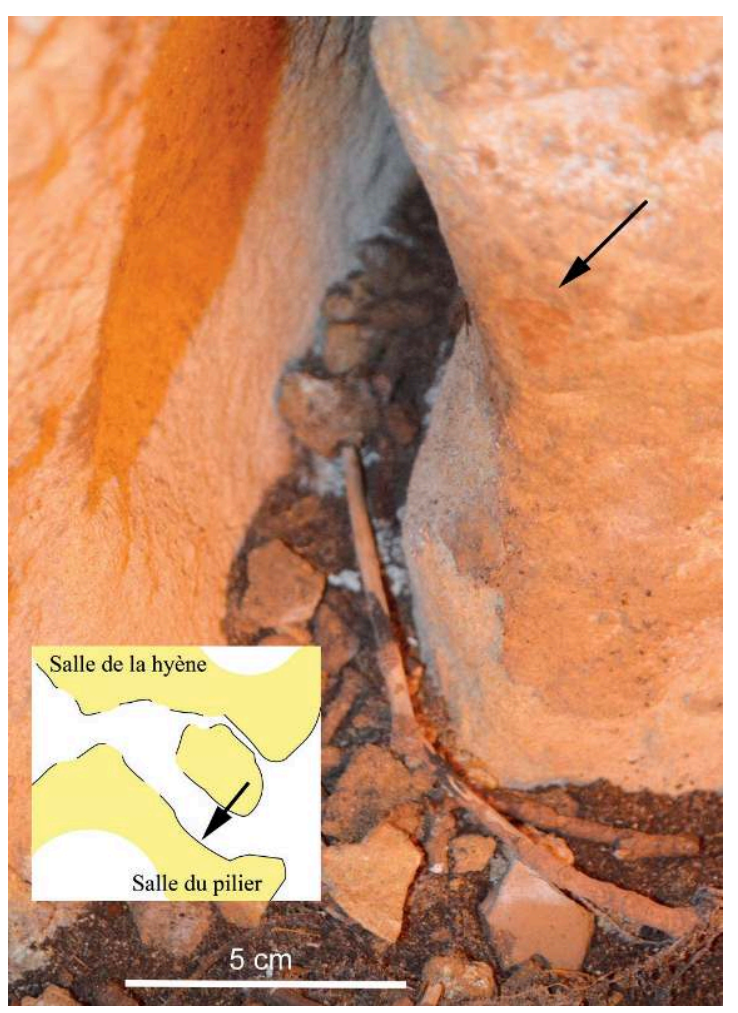




\subsection{2 - The slope profiles} archaeological site loci: the first (orange) recorded to the level of La Roche Cotard I and II cave, the second (blue) recorded at the level of LRC III, the third at the level of LRC IV (green). The profile of the slope outside of the area of soil removal (red) is clearly different from the other three by a convex bending (in B) due to the presence of the tuffeau chalk wall that appears today in the outcrop at the entrance of LRC I but that remains deeply buried at the level of LRC IV. The middle (BC) and low (CD) parts of the zone outside of the removal area give a shape that can be described as an equilibrium profile, connecting the modern alluvium of the Loire, at an altitude of 42 meters NGF (General Levelling of France), at the edge of the park, along the Cinq-Mars-la-Pile road.

At the level of the upper third (AB) of the slope, the three profiles of the removal area are virtually coincident. At the height of LRC I, they connect with the top of the overhang, which is above the entrance of the cave. At the level of LRC III and IV, two meters of sediment are still separating the top of the limestone wall from the present surface of the slope. In these three places, the lack of sediment could be due not to the direct removal of soil by modern diggers because we're very high on the slope, but rather to a regularization of the slope profile, subsequent to the removal, through water runoff and gravity, with the rocky ledges, notably the one of LRC I, preventing an easy flow of the soil downwards. These rocky overhangs have significantly slowed the advance of the diggers while some twenty meters to the west, the soil removal was much larger and resulted into a soil high slope, still impassable on foot today because it is too abrupt.

In the middle third (BC) of the slope, the profiles of LRC III and IV (green and blue) join the equilibrium profile (red). For LRC III, this is due to the presence of the chert massive that forms the roof of the shelter and probably also the cliff (unobserved) located directly above the roof of the shelter. The soil removal has been pushed to the maximum here to really reach the vertical of the shelter front, the limit having been observed during the excavation of this locus. For LRC IV, there was still some room for the diggers before reaching the tuffeau wall as here the cliff recesses to the north, the roof of LRC III forming a large overhang towards the south. Then presumably having been blocked in their advance by the prominence of the shelter, the diggers did not insist, considering that at the LRC IV level, the wall was close by.

51 As for the orange profile at the entrance of the cave, the soil removal was very important there as it revealed, or almost, not only the space in front of the entrance, but also all the space along the tuffeau cliff to the west, up to where the cliff recesses toward the north, to reach a kind of new small rocky cove similar to the one in front of the entrance of LRC I. When d'Achon discovered the cave, there was only one opening the size of a burrow and it seems that the soil then reaching the top of the entrance was unaffected by the works or accumulated, later, by gravity.

In the lower third (CD) of the slope, the three profiles of the site, very close, divert significantly from the equilibrium profile (red) of the slope. The mass of washed away material is easily identifiable and could even be quantified. The fact that the three profiles of La Roche-Cotard I / II, III and IV broadly coincide result from the fact that the diggers stopped taking materials when they met the first obstacle, namely the roof and the base of LRC III. In front of LRC I, the digging has been very important until 
meeting the cliff to the north. To the west, the extraction was much advanced along the cliff and then further.

The total occultation of the entrances to the cave (LRC I) and the cave-shelter (LRC IV) by the slope deposits in place until 1856, which led to the discovery in 1912, is to retain from this analysis of the slope profiles. Since then, with the exception of very few visitors (one modern graffiti), access to the cave was protected only by its location in a walled property. It was visited by the workers of F. d'Achon (traces of pick at the base of some walls and on the floor in front of the entrance of the corridor) and by the excavation teams of the years 1970 and 2000. It is not possible to imagine that d'Achon's workers could have done these careful rhythmic traces, placed over selected areas of the walls. This is all the more so for the four red dots.

Finally, we should question the date of the setting up of these slope deposits to try and venture a guess as to the age of these tracings. To address this chronological point, we must return to the stratigraphy and the chronology of the sediment that formed the filling of the cave.

\section{2 - The filling}

LRC I cave is dug into the tuffeau chalk under the Senonian base, between altitudes of 48 and 52 meters ASL. Figure 21 shows the longitudinal section of the proximal portion of the cave along the tracing from $\mathrm{E}$ to $\mathrm{H}$. As we approach the entrance to the cave, the profile collapses slightly and shows a slight deepening guided by the large chert masses herein.

Thanks to the stratigraphic observations carried out on the remains of layers that have been presented above, we can replace, at the entrance of the cave, the stratigraphy as follows:

- at the base, in front of the imposing chert mass of the entrance, the lower layer (i) that contained the rich Mousterian level. It covered the hearth pit drawn on d'Achon's plan and is still visible today (its deeper point is at $48.03 \mathrm{~m}$ ). It reached the base of the middle layer remain $(\mathrm{m})$ still present under the oblique chert plaque of the external wall close to the entrance at $48.72 \mathrm{~m}$. It is about $50 \mathrm{~cm}$ thick as the depth of the soil is close to $20 \mathrm{~cm}$;

- Above, the middle layer $(\mathrm{m})$, thick and heterometric made of a probable flood silt of the Loire (Macaire in Marquet 1997 - p.34). Its base was truly observed only under the sloping slab quoted above where we found a Levallois flake and a spherical artefact, marking the top of the lower layer (i). The top of this overflow silt, considering it has not undergone erosion before the deposition of the top layer that covers it, was observed in the P2 passage (fig. 21) which connects the Lemmings Chamber with the outside; its altitude is $50 \mathrm{~m}$ asl. Its total thickness is of the order of $1.30 \mathrm{~m}$;

- Above this overflow silt, contrasting sharply with it, the top layer (s) was found in the same P2 passage. It is still present, in place on the site. It contains no artefacts but is rich in faunal remains and especially micro-fauna, mainly rodents, which confirm the very cold characteristic of the climate episode (collared lemming, narrow headed vole). About the nature of the sediment, J.-J. Macaire (In Marquet 1997 - p. 35) notes that it is "sandy clay sediment ... containing many fragments of chert, often angular and flattened. The appearance of the quartz grains... and the average grain size of the sand are consistent for wind origin although the classification is wrong." The same author concludes: "...part of the sediment (east) from the cave itself, especially the cristobalite and the numerous chert 
grains and platelets that were generated by gelifraction... the rest was blown from the alluvium of the Loire located outside of the cave... " The presence of very numerous rodent remains confirms this external source, as the birds of prey that left these remains must have nested on the wall above this corridor. The top of this layer, inside the chamber of the Lemmings is at $50.58 \mathrm{~m}$. This layer was dated on a bone by $14 \mathrm{C}$ to between 34,795 and 35,942 BC cal. (Lyon 6962) and on the sediment to $64,100 \pm 5,100$ by the OSL method (MFGI Budapest).

57 If it is difficult to know the extent, both inward and outward of the cave, of the top layer (with cryoclastic elements and faunal remains of cold climate), however it is certain that this overflow silt of the middle layer would naturally extend widely in front of the cave. The same overflow silt is present in the filling of La Roche-Cotard III; it made the largest part of it but at an altitude much lower than the deposit in LRC I. However, LRC IV, at about the same altitude as in LRC III, contains fluvial deposits slightly different from the overflow silt but with decantation figures (presence of particularly thin beds, some composed almost exclusively of mica flakes from the alluvium of the Loire) that may be close to it.

This silt layer was subsequently eroded whether by new overflows of the Loire, or simply by erosion due to water running on the slope. During one, or more probably several, subsequent climatic phases, it is likely solifluction materials (sediment mostly from the plateau, highly heterometric, composed of a matrix rich in sands and clays and containing, without stratification or other organization, elements of varying size and pluricentimetric) did set up on the slope. Thus, throughout the period of occupation of the site four loci, whose duration is difficult to estimate, the Loire was close to the slope, even depositing alluvium at its foot (LRC II and IV but also seen, a little further upstream through drilling by the SRA - Marquet ibid). Subsequently, in favour of cold climatic episodes, indicated by the upper layer of La Roche-Cotard I, the solifluction material from the plateau completely covered the slope. 
Figure 20 - Profiles of the slope of the site of La Roche-Cotard.

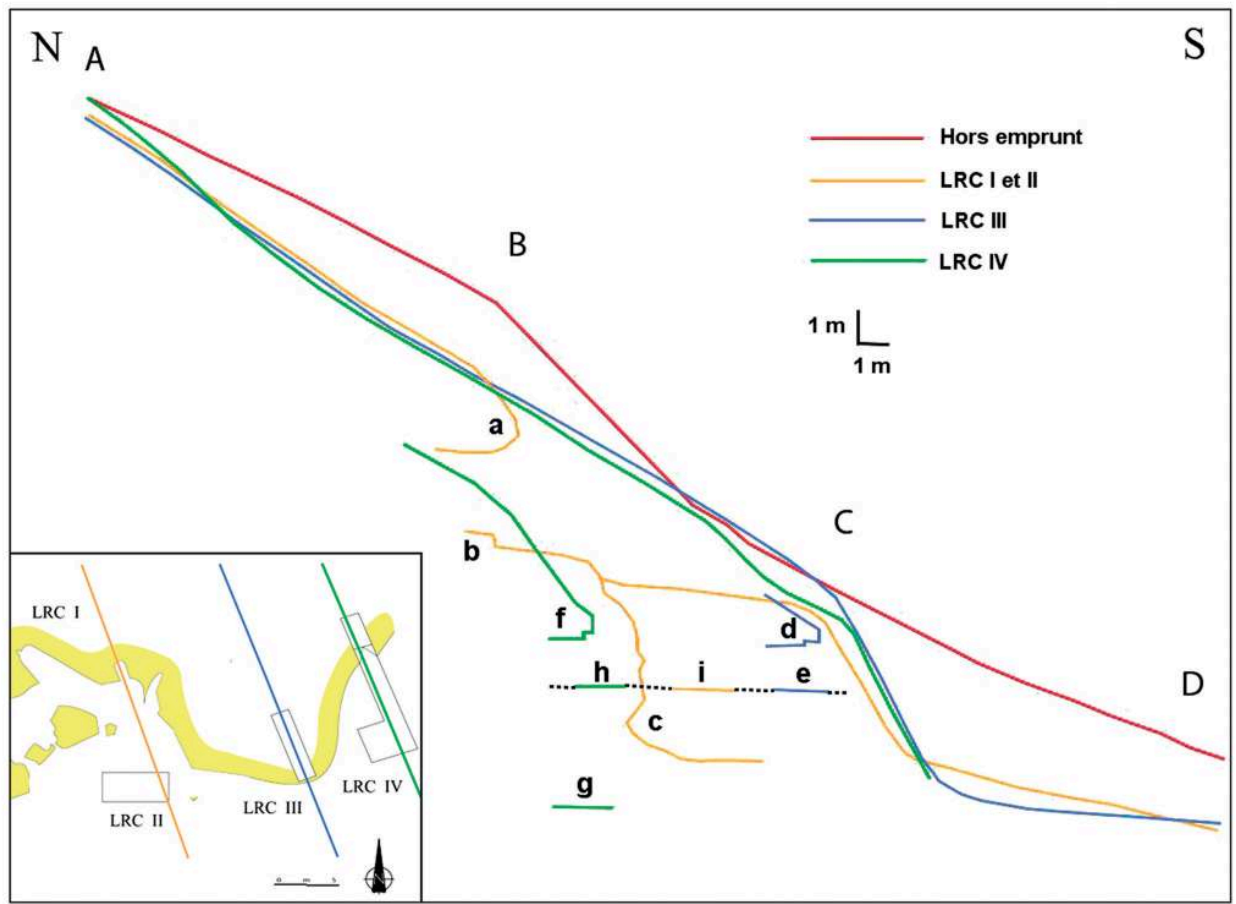

RED : THE PROfILE OUTSIDE THE PLACE OF EXTRACTION OF MATERIALS IN 1846. ORANgE : ACTUAL PROfile AT THE LRC I AND LRC II LEVEL, BLUE : ACTUAL PROfILE AT THE LRC III LEVEL, GREEN : ACTUAL PROfile AT THE LRC IV LEVEL. A: FRONT OF THE ENTRANCE OF LRC I; B. BASE OF THE ENTRANCE OF LRC I; C : BASE OF THE WALL ON WHICH LEANS LRC II; D: FRONT OF LRC III; E: FLOOR OF LRC III FORMED BY THE BED OF HARD LIMESTONE; F: FRONT OF LRC IV; g: FLOOR OF LRC IV; H: BED OF HARD LIMESTONE IN LRC IC; I: BED OF HARD LIMESTONE IN LRC II. THE LETTERS A, B, C ET D INDICATE THE LIMITS OF THE THREE PARTS, UPPER (AB), MEDIUM (BC) AND LOWER (CD) OF THE SLOPE. DOWN, ON LEFT, LOCALISATION OF THE THREE PROfiLes OF THE SITE.

Figure 21 - La Roche-Cotard I.

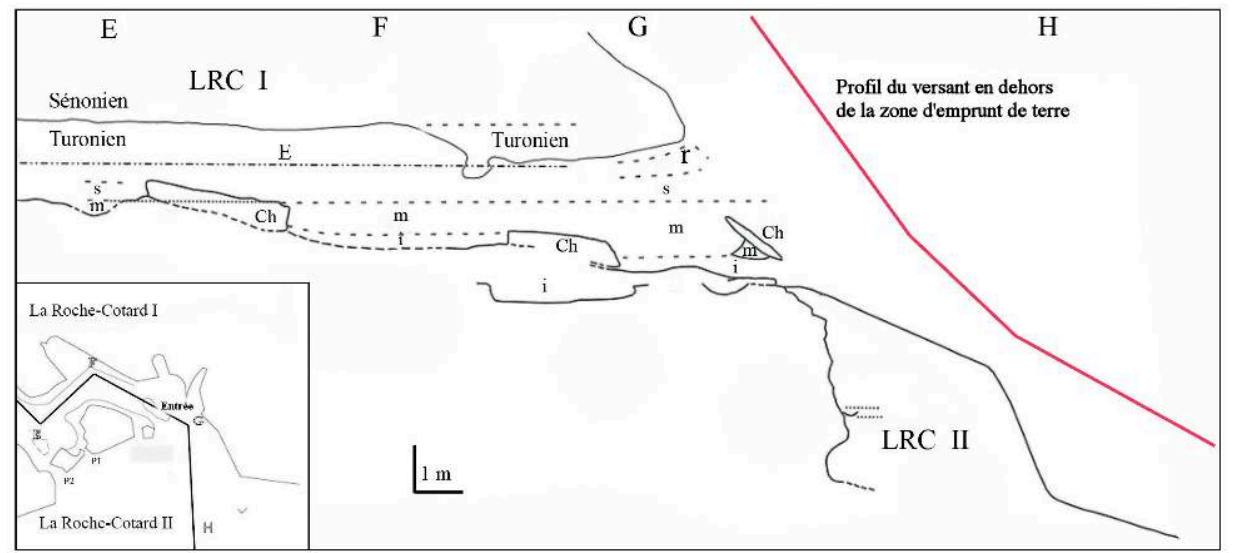

ADAPTED LONgITUDINAL PROfILE OF THE CAVITY ACCORDINg TO THE PLAN ON LEFT. SEDIMENTARY fILLING : I: INFERIOR LAYER; M: MIDDLE LAYER; S: SUPERIOR LAYER; R: REWORKED; CH. TURONIAN CHERT; E : CLEFT IN THE FORM OF INVERTED STAIRS DUE TO THE WATER THAT HAS STAGNATED ON THE INSIDE OF THE CAVITY FOR A VERY LONg PERIOD AND WITH AN OVERFLOW SYSTEM. 


\section{3 - Dating}

The slope deposits of La Roche-Cotard IV are still masking today the entrance to the shelter cave. These formations have been dated by $14 \mathrm{C}$ thanks to the very few bones they have yielded (fig. 22). One of them, from the top of the layer 7a (D1), found in the square Q9, at an altitude of $46 \mathrm{~m}$, gave an age of 31,048 to $29,486 \mathrm{BC}$ cal. (Lyon 9087). It does not date the beginning of these solifluction setting up as it is situated geometrically approximately "half-way" of this deposit. Dating by the OSL method of sediment near the base of layer 7c (D2), sampled in square Q5, gave an age of 48,100 \pm 3,800 years (MFGI Budapest). Another $14 \mathrm{C}$ dating of a bone from the top of the filling at the entrance of the cave shelter (D3), in layer 9 (at the level of square R4), confirms a date over 44,600 years (Lyon 10160 ).

These dating allow concluding that at the level of La Roche-Cotard IV:

- The filling of the cave-shelter has reached the ceiling around 44,000 years or earlier;

- A phase of erosion has removed all the part of the layers 2 to 9 that is ahead of the front of the cave-shelter;

- The deposits on the slopes did set up from at least 40,000 years.

Around 30,000 years, the entrance to the cave-shelter had already long been obscured, the colluvium continued to accumulate and hid the Turonian cliff completely.

In front of the entrance to the d'Achon cave (LRC I), we were able to date the middle layer (flood silt) thanks to the remains protected at the bottom of a small niche (D11). The OSL dating gave an age of 72,600 $\pm 6,000$ years (MFGI Budapest); we are waiting for the radiocarbon date. However the $14 \mathrm{C}$ dating of the same layer, inside the cave, gave an age over 40,000 years (Lyon 6961) for a bone from the P2 corridor between the Chamber of the Lemmings and the outside of the cave (D10) and 38,060 \pm 940 BP (Lyon 7864) for a bone from a niche in the Mousterian gallery. On the same layer, a previous dating had given us an age higher than or equal to 38,400 years (Gif 4447).

3 Still in La Roche-Cotard I, the upper layer remains in the same P2 corridor from the Chamber of the Lemmings toward the outside, was dated (D8) by $14 \mathrm{C}$ to $34,795-35,942$ BC cal (Lyon 6962) while the OSL method (D9) gave an age of 64,100 $\pm 5,100$ years (MFGI Budapest).

64 The sediments sampled in front of the entrance of the cave, in its entrance and in a corridor that connects directly the cave with the outside were dated. These results allow asserting, for La Roche-Cotard I only, that:

- The flood silt layer (middle layer) that closes most of the entrance to the cave was set up no later than 35 and 40,000 years;

- The upper layer corresponding to a particularly cold climate episode covers the underlying layer at the latest by 35,000 years, probably before an important erosive phase (flowing of the river at the foot of the slope) that removed, as in front of the LRC III shelter and the cave-shelter LRC IV, most of the deposited materials, except the trapped sediment. 
Figure 22 - La Roche-Cotard I et IV. Correlation between the three main levels of LRC I with the deep levels of LRC IV.

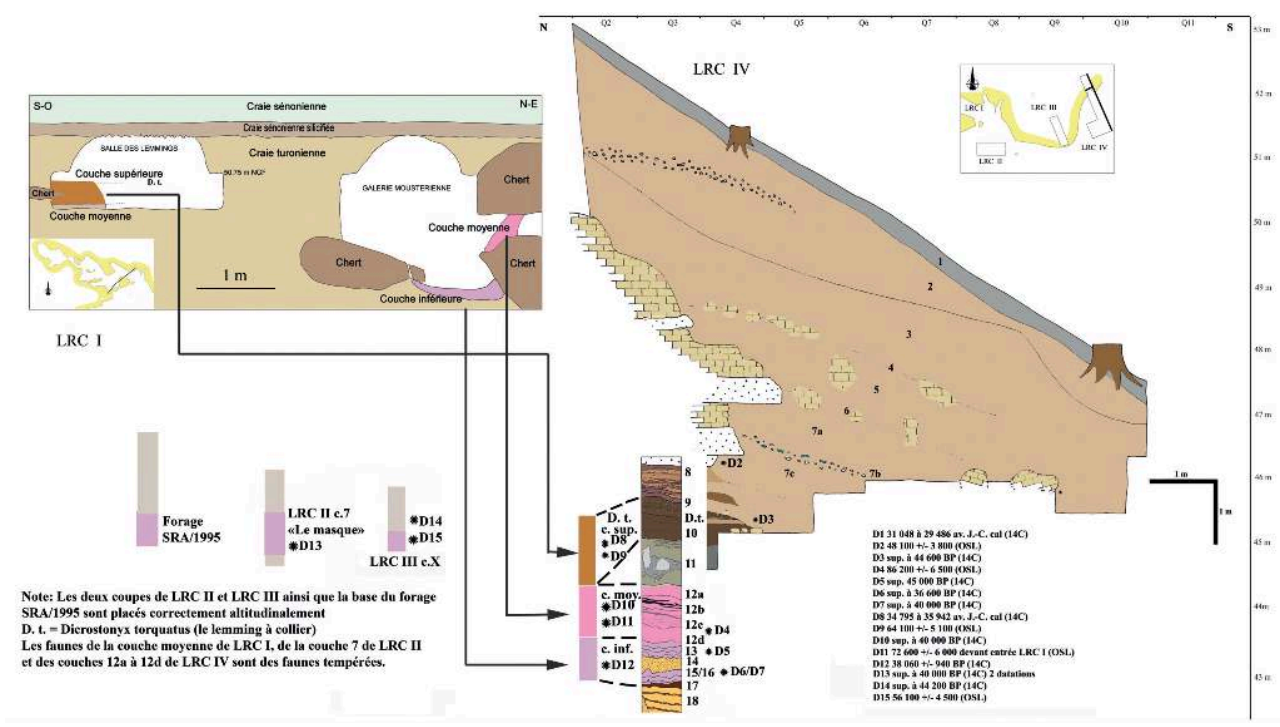

THE TWO SECTIONS ARE SITUATED WITH THE SAME ALTITUDE SCALE. THE SIMPLIFIED STRATIgRAPHIC LOg OF LRC II, LRC III AND THE BORINg OF SRA/1995, HAVE BEEN ALSO PLACED ON THE SAME SCALE; THE LEVELS WITH LITHIC INDUSTRY OF THE TWO LOCUS ARE AT AN ALTITUDE LIGHTLY HIgHER THAN THOSE OF LRC IV. THE MOUSTERIAN LEVEL IN THE CAVE OF LRC I IS CLEARLY ABOVE THE THREE OTHERS.

\section{7 - La Roche-Cotard's finger tracings: assumptions and conclusions}

35 to 40,000 years ago, the cave was largely filled with sediments from the Loire deposited by winnowing from the alluvium of the river that flows right down the slope and through the provision of cryoclastic elements from the rocks up the cliff and the walls of the cave near the entrance. When d'Achon entered the cave through a burrow, there remained at the entrance, only a 20 to $30 \mathrm{~cm}$ high passage. The geometry of the residual slope deposits, which mask the LRC II station at the foot of the wall, the LRC III shelter and the cave-shelter IV, and of the current slope deposit outside the removal zone, lead us to consider that before the digging period, residual deposits, and also the entrance of the d'Achon cave were hidden by the accumulated materials. The slope formations that now seal the cave shelter LRC IV (fig. 22) began to build up at least 35,000 years ago, as indicated by the dating obtained. Given the terrain, it is impossible that these deposits did not also affect the entrance of the d'Achon cave, which was already filled with sediment preserved from erosion almost to the ceiling in all its proximal part, in the same way they flooded the whole slope as seen today outside the removal area. In conclusion, the cave was closed, at least 35,000 years ago, by deposits that have accumulated almost to its ceiling, then by the slope colluvium that completely hid it.

This complex site includes at least four loci inhabited by humans who left their traces in the form of artefacts, food remains, and utilitarian structures (pit-hearths, blocks structures). No evidence of occupation by modern Man was found. However, Neanderthals indicate their presence by a characteristic toolkit (side scrapers, triangular bifaces, Levallois debitage, retouchers on bone). It is obvious that the 
Mousterian hunters visited this site several times despite the lack of on-site quality raw material for the production of their tools.

We have presented the main panels of digital tracings (or done with a tool), the most readable. These lines, we may call them "decorations", were not made anywhere on the wall: even if it is likely that some panels have been completely erased, their locations appear to have been carefully chosen. This is the case for example of the triangular panel that covers a surface offered by the morphology of the wall. The parallel lines are careful, applied, rhythmic, perhaps reflected as seen near the large preserved silt triangle where the fingers, unlike the long vertical tracks made with one line, seem to have passed slowly, through a series of somewhat stronger pressures as if to emphasize the relief that they wanted to preserve. The care with which the surface was covered with organized traces, the preservation of some parts left in relief, the shape of this surface, the presence of the chert cylinder at the corner, at the bottom of the triangle surprises us and makes us wonder.

We must recall the complete absence of any evidence of industry posterior to the Middle Palaeolithic in the intact layers of the site, a logical absence given the ancient setting up of the slope deposits. As for the tracings, and the ochre stains found in the cave, it is impossible to envisage their making during the 1912 work: for the traces of ochre, due to their difficult location; for the tracings, the care with which they were made, the alteration they suffered, so gentle and gradual from one end of the panel to the other exclude any recent making. Therefore, we can only propose the hypothesis that the lines, as well as the four red ochre stains, were done by Neanderthals, the only Humans to occupy the cave before it reopened in 1912. We do consider that the mask of La Roche-Cotard II is a protofigurine also produced by the Neanderthals, but no evidence, however, allow us to propose any contemporaneity of these symbolic productions.

\section{8 - Conclusion}

Research on the beginning of rock and cave art continues to progress through new discoveries and corrections of errors and earlier assumptions. Thus, for example, the walls covered with cup marks in the Daraki Chattan cave (Madhya Pradesh) attributed to the Acheulean by G. Kumar and R. Bednarik proved non-datable in a recent review of the site, the cave having been invaded by debris from the surface, the few archaeological remains contained in these exogenous deposits were without confirmed relationship with parietal cupmarks (Lorblanchet 2013).

The tradition of the cupmarks, however, has a much earlier origin than the Upper Palaeolithic. The Neanderthal burial No. 6 in La Ferrassie, now dated to around 50,000 years, was covered with a stone with cupmarks. On the same site, this tradition continued regularly in the Aurignacian overlying levels where it gave birth to a figurative art on blocks and then to engravings by cupmarks on cave wall, like for example in the Belcayre shelter in the Dordogne and the Fieux cave in the Lot (Lorblanchet 1999, 2006). In addition, U-Th dating of dots and hand stencils of eleven Spanish caves (including Castillo, Altamira, Tito Bustillo) obtained in 2012 by the team of A.W.G. Pike and D. Hoffmann (Pike et al. 2012; Pike and Petitt 2012) confirm the extension of the Palaeolithic art chronology already indicated by AMS dating. We have 
returned today (unsurprisingly for some) to the "400 centuries of parietal art" of the title of H. Breuil's famous book published in 1952.

These U-Th dates focus on the long duration of parietal art, that is to say, on a probable heterogeneity of forms and contents, leading to the acceptance of breaks within a stylistic evolution that was thought univocal with the gradual ascent to the pinnacle of naturalism. Already Chauvet, Cussac, Lascaux, Altamira, the open-air art of the Côa, appeared to us as absolute masterpieces, in splendid isolation, fitting with difficulty into an overall stylistic evolution. A question posed again by the U-Th dates is that of the existence of a single evolution or of a stylistic kaleidoscope for the immense duration of parietal art.

The dates of some parietal decorations beyond 35,000 years and around 40,000 years most recently confirmed in Indonesia (Aubert et al. 2014) - correspond, in Europe, to the period contemporary to Neanderthals and modern humans; the question of the authorship of the European cave art is thus clearly posed: is the oldest cave art exclusively the work of modern Man? Is it not sometimes the work of the Neanderthals? Certainly, the dating methods by Uranium-Thorium are still at an experimental stage that can have limits (White et al. 2012; Pons-Branchu et al. 2014), but they are now experiencing significant progress and are opening a vast horizon to the dating of all forms of rock and cave art. They should therefore be encouraged. The recent discovery of an engraved parietal sign in Gorham's Cave in Gibraltar (Kambiz Kamrani 2014) suggests, besides, the existence of Mousterian parietal engravings. The archaeological and geological data of La Roche Cotard thus provide new elements that go in the same direction... that the Neanderthals may be the authors of some nonfigurative finger tracings, as well as dots in red ochre or some hand stencils or engraved lines, these are assumptions that are needed today: the old paradigm of the emergence of rock art in the West due to the advent of a new human species can now be doubted.

\section{BIBLIOGRAPHY}

ACHON (d') F. 1913 - Au pays des châteaux. La Roche-Cotard. Sa grotte préhistorique. La Touraine $1^{\text {ère }}$ année, $\mathrm{n}^{\circ} 4$.

AJAS A. 2011 - Étude géoarchéologique du gisement paléolithique de La Roche-Cotard I et IV (Langeais, Indre-et-Loire). Rapport inédit. PACEA, UMR 5199, Univ. Bordeaux 1, 28 p.

AUBERT M., BRUMM A. RAMLI M., SUTIKNA T.D., SAPTOMO E.W., HAKIM B., MORWOOD M.J., VANDENBERGH G.D., KINSLEY L., DOSSETO A. 2014 - Pleistocene cave art from Sulawesi, Indonesia 9 oct. 2014 Nature vol 514 p. 222-240.

AUJOULAT N. et CHEVILLOT C. 1989 - Une découverte exceptionnelle à Saint-Martin-deFressengeas (Dordogne) : la grotte des Fraux , Documents d'Archéologie et d'Histoire Périgourdines, 4, p. 39-44, 2 fig. 
BALLARD C. 1992 - First Report of Digital Fluting from Melanesia. Rock Art Research 9, n² 2, 1992, p. 119-121.

BEDNARIK R. 1986 - Parietal finger Markings in Europe and Australia. Rock Art Research, volume $3, \mathrm{n}^{\circ} 1$, p. 30-61.

BEDNARIK R. 1994 - The Discrimination of Rock Markings. Rock Art Research, 1994, volume 11, ${ }^{\circ}$ 1, p. 23-44.

BEDNARIK R. 2014 - The known cave art sites of Australia. Voir : http://www.ifrao.com/wp-content/ uploads/2014/06/Cave_table.doc

BYRNE N., DELPECH F., PRAT F. 1997 - La Roche-Cotard. Répartition des restes osseux. In : Marquet J.-C. 1997, p. 37.

DUVALL D. 2010 - Finger fluting and other cave art in Cumayasa, Dominican Republic Rock Art Research, 2010, volume 27, $\mathrm{n}^{\circ}$ 2, p. 1-10.

KANBIZ KAMRANI 2014 - 40000 years old Neanderthal Hashtag Engravings from Gorahm's cave in Gibraltar; Anthroplogy.net 2 sept. 2014

LORBLANCHET M. 1995 - Les grottes ornées de la préhistoire. Nouveaux regards. Paris : Éditions Errance, $288 \mathrm{p}$.

LORBLANCHET M. 1999 - La Naissance de l'Art, genèse de l'art préhistorique. Paris, Editions Errance, $304 \mathrm{p}$.

LORBLANCHET M. 2006 - Les Origines de l'Art, Paris, Éditions du Pommier, Cité des Sciences, 187 p. LORBLANCHET M. 2008 - Visite à la grotte de La Roche-Cotard (Indre et Loire). Rapport inédit. 5 p. In Rapport d'opération de sondage. Marquet J.-C. 2008, Service régional de l'archéologie du Centre. LORBLANCHET M. 2013 - Les débuts de l'art rupestre dans le monde, In : Colloque de l'École Pontificale des Sciences, Rome 2013, à paraître aux éditions du CNRS.

MAN-ESTIER E., PAILLET P. 2009 - Rapport d'étude. La Roche-Cotard. Inédit 2 p. In : Marquet J.-C. 2009, Rapport de fouille programmée. Service régional de l'archéologie du Centre.

MARQUET J.-C., BYRNE N., DELPECH F., MACAIRE J.-J., PRAT F. et RAGE J.-C., 1979 - Un grand site préhistorique en Touraine. La Roche-Cotard à Langeais. Grotte et station du paléolithique moyen. Laboratoire de Géologie. Faculté des sciences. Université François Rabelais, Tours, 1979, 175 p. 64 fig.

MARQUET J.-C., AUBRY T., BYRNE N., DELPECH F., DESSE G., MACAIREJ.-J., PRAT F., RAGE J.-C., URBAN B., VISSET L. 1997 - Le site préhistorique de La Roche-Cotard à Langeais (Indre-et-Loire). Ed. CLD Chambray-les-Tours, 127 p., 82 fig, 24 tabl., 6 pl. hors texte.

MARQUET J.-C., LORBLANCHET M. 2000 - Le masque moustérien de La Roche-Cotard, Langeais (Indre-et-Loire), Paleo, $\mathrm{n}^{\circ} 12$, p. 325-338.

MARQUET J.-C., LORBLANCHET M. 2003 - A Neandertal face ? The protofigurine from La RocheCotard, Langeais (Indre-et-Loire, France), Antiquity volume 77, n² 298, p. 661-670.

PETROGNANI S., BOURRILLON R., BURENS A.,CAROZZA L. 2014 - A la poursuite du temps court : les expressions pariétales de l'âge du Bronze de la grotte des Fraux (Dordogne, France) Paleo numéro spécial 2014 p. 163 à 169.

PETZINGER G. von, NOWELL A. 2011 - A question of style: reconsidering the stylistic approach to dating palaeolithic parietal art in France, In : Antiquity, volume 85, n 330 , p. 1165-1183. 
PIKE A.WG., PETITT P. 2012 - Redating Ice Age Art; were Neandertals the first artists in Europe? Current World Archaeology, Issue 55, p.22-27

PIKE A.WG., HOFFMANN D., GARCIA-DIEZ M., PETITT PGB., ALCOLEA J., BALBIN R.de, GONZALESSAINZ G., LAS HERAS C. de, LAS HERAS J.A., MONTES R., ZILHAO J. 2012 - U-series Dating of paleolithic Art in 11 caves in Spain, SCIENCE, vol 336, 15, june 2012, p.1409-1413

PONS-BRANCHU E., BOURILLON R., CONKEY M., FONTUGNE M., GARATE D., QUILES A., RIVERO O., SAUVET G., TOSELLO G., VALLADAS H., WHITE R. 2014 - Uranium-series dating of cartonate formations overlying Paleolithic art, interest and limitations. Bulletin de la Société préhistorique Française,2014-2, avril-juin p.211-224.

RIALLAND Y., DETRAIN L., LENOBLE A. 1995 - A-85. Contournement nord de Langeais (Indre-etLoire). La Roche-Cotard. Rapport d'étude d'impact. Ministère de la Culture. Préfecture de la Région Centre. DRAC. Service régional de l'Archéologie. 46 p. 19 fig. 6 pl. photo.

SHARPE K. 2004 - Line Markings : Human or Animal Origin? in Rock Art Research, p. 57-84.

SHARPE K., VAN GELDER L. 2004 - Les enfants et «l'art» paléolithique : indices à la grotte de Rouffignac, France, Inora, 38, p. 9 - 16. Voir http://www.international.icomos.org/ centre_documentation/inora/inora38/inora-38-3.pdf, (vu le 21/07/2014).

SHARPE K., VAN GELDER L. 2005 - Techniques for Studying Finger Flutings. Society of Primitive Technology Bulletin, 30, p. 68-74.

THAMO-BOZSO E. 2013 - Results of OSL dating La Roche-Cotard LRC/OSL/1-6 samples et Results of OSL dating La Roche-Cotard LRC/OSL/7 sample. Inédits, Magyar Fölsdtani és Geofizikai Intézet, Budapest, 16 p. et 6 p.

TOURON S., BOURGES A. 2012 - Langeais (37, Indre-et-Loire). Grotte de La Roche-Cotard. Identification d'argile et concrétion blanches. Rapport d'étude inédit. Laboratoire de recherches des monuments historiques. Champs-sur-Marne.

VAN HOEK M. 2011 - Aldea de Ramaditas, Chile: Architectural Art or Rock Art? Voir http:// www.rupestreweb.info/aldearamaditas.html (vu le 21/07/2014).

WHITE R., MENSAN R., BOURRILLON R., CRETIN C., HIGHAM T., CLARK E., SISK M., TARTAR E., GARDÈRE P., GOLDBERG P., PELEGRIN J., VALLADAS H., TSINERAT-LABORDE N., SANOIT (de) J., CHAMBELLAN D., CHIOTTI L. 2012 - Context and dating of Aurignacian vulvar representations from Abri Castanet, France, In : PNAS, T. 109, n 22, p. 8450-8455

WINTLE A., MURRAY A.S. 2006 - A review of quartz optically stimulated luminescence characteristics and their relevance in single-aliquot regeneration dating protocols. Radiation Measurements 41, 369-391.

\section{NOTES}

6. Vernacular name given to this rock. 


\section{ABSTRACTS}

La Roche-Cotard site is located on the right side of the Loire valley, about $20 \mathrm{~km}$ down-river from Tours. The site, uncovered in 1846, following the extraction of materials, was excavated in 1912. Research was taken up again from 1975 to 1978, then from 2008 onwards.

The first reprise of excavations in 1975 allowed for the discovery, at the entrance of a cave on a beach of the Loire on which Neanderthals have made fire, of stone tools and a proto-figurine that was named by M. Lorblanchet the "Mask of La Roche-Cotard" (Marquet \& Lorblanchet, 2000, 2003). A very low shelter was also discovered, which contains some stone tools and a layout of blocks on the ground.

The second reprise of excavations in 2008 allowed for the discovery of a small cave-shelter filled with sediments, presenting also indications of occupation by Neanderthals; but above all it enabled further work on the inside of the main cavity.

Deeper examination of the cave walls, carried out by J.-C. Marquet, with the support of M. Lorblanchet, P. Paillet and E. Man-Estier, allowed for the recognition of three panels of finger flutings and a panel of point-marks. These marks are visible due to the removal of matter (by hand or with the aid of an instrument giving the same type of marks) on the weathered «tuffeau chalk » wall, recovered by a thin film of silty clay. On one of the panels can be observed a circular representation, on the other two, sets of parallel markings, organized and rhythmic. Four red ochre stains were also discovered.

Geometric, granulometric and morphologic studies of the deposits, as well as ${ }^{14} \mathrm{C}$ datings of bones and datings of sediments through the OSL method, show that following the occupation by Neanderthals, the entrance to the cave was blotted out and was only reopened in 1846, or even in 1912.

No direct dating of the markings is possible. However, their localized weathering, datings of bones and sediments found just in front of the panels and naturally the closure of the cave's entrance after the occupation by Neanderthals allows us to rule out the possibility of a recent age.

Mask, markings and traces of painting in a cavity inaccessible to Homo sapiens until 1846, geometry of deposits, all add to the great interest in La Roche-Cotard site, at the very moment when we reconsider seriously the question of the competences of the Neanderthals.

Le site de La Roche-Cotard se trouve sur la rive droite de la vallée de la Loire à une vingtaine de kilomètres en aval de Tours. Le gisement, mis au jour en 1846, suite à l'extraction de matériaux, a été fouillé en 1912. Les recherches ont repris de 1975 à 1978, puis à partir de 2008.

Les premières recherches, en 1975, permettent la découverte, devant l'entrée de la grotte, d'un lambeau de plage de Loire sur lequel les hommes de Néandertal ont allumé un feu, abandonné des pièces d'industrie lithique et une protofigurine, appelée par M. Lorblanchet « masque de La Roche-Cotard " (Marquet, Lorblanchet 2000, 2003). Un abri très bas est également découvert ; il contient un peu d'industrie lithique et un aménagement de blocs au sol.

À partir de 2008, les nouvelles fouilles mettent au jour une petite grotte-abri comblée de sédiments, présentant également des indices d'occupation par l'homme de Néandertal. Elles poursuivent également le travail à l'intérieur de la cavité principale.

L'examen approfondi des parois, effectué par J.-C. Marquet avec les appuis de M. Lorblanchet, P. Paillet et E. Man-Estier, permet de reconnaître quatre panneaux, trois de tracés digitaux et un de ponctuations. Ces traces sont visibles car il y a eu enlèvement de matière (au doigt ou à l'aide d'un instrument pouvant donner le même type de trace) sur la paroi de "craie tuffeau " (nom vernaculaire donné à cette roche) altérée, recouverte par un mince film de limon argileux. Sur 
l'un des panneaux, on observe une figuration circulaire, sur les deux autres des ensembles de tracés parallèles, organisés et rythmés. Quatre taches ocre rouge ont été repérées.

Les études géométrique, granulométrique et morphologique des dépôts, ainsi que les datations des os par le ${ }^{14} \mathrm{C}$ et des sédiments par la méthode OSL, montrent qu'après l'occupation par les hommes de Néandertal, l'entrée de la cavité a été occultée, pour n'être réouverte qu'en 1846 (voire seulement en 1912).

Aucune datation directe des tracés n'est possible. Cependant, leur altération locale, les datations des os et des sédiments situés juste devant les panneaux et naturellement celle de la fermeture de l'entrée de la grotte après l'occupation par Néandertal autorisent à exclure un âge récent.

Masque, tracés et traces de peinture dans une cavité inaccessible à Homo sapiens jusqu'en 1846, géométrie des dépôts, confèrent au site de La Roche-Cotard un très grand intérêt au moment où est sérieusement reconsidérée la question des compétences de l'homme de Néandertal.

\section{INDEX}

Keywords: finger flutings, rock art, red ochre, symbol, Middle Palaeolithic, Neanderthal, Mousterian, Touraine

Mots-clés: tracés digitaux, art pariétal, ocre rouge, symbolique, Paléolithique moyen, Moustérien, Néandertal, Touraine

\section{AUTHORS}

\section{JEAN-CLAUDE MARQUET}

Chercheur associé, Laboratoire Archéologie et Territoires Tours, UMR 7324 CITERES,16, Place

Richemont, FR-37550 Saint-Avertin - jcmarquet@wanadoo.fr

\section{MICHEL LORBLANCHET}

Directeur de recherches honoraire au CNRS - michel.lorblanchet@wanadoo.fr

\section{YVES EGELS}

École Nationale des Sciences Géographiques, Champs-sur-Marne - yves.egels@free.fr

JOSÉ ESQUERRE-POURTÈRE

Professeur de S.V.T., FR-59239 Thumeries - jose.esquerre-pourtere@wanadoo.fr

\section{MARIA-SIBYLLA HESSE}

Professeure d'Histoire et de l'Histoire de l'art à l'École Waldorf de Potsdam (Allemagne) sibylla.hesse@posteo.de 